\title{
O Azul na História da Moda
}

Ana Júlia Neres Bariani

Anna Gabriela Seiko Ferraz Taguchi

Beatriz Nogueira Alves

Leandro Arcanjo Ferreira da Silva

Thais Malta dos Santos*

DOI: $10.11606 /$ issn.2318-8855.v10i2p148-190

Resumo: Pesquisas indicam que o azul é a cor preferida de mais da metade da população ocidental. Porém, existem poucas pesquisas acerca dessa cor na indumentária dos países do ocidente. Nesse sentido, esse artigo tem como objetivo investigar o uso da cor azul nas vestimentas utilizadas pelas sociedades dos diferentes períodos históricos; com foco nas sociedades ocidentais. Para tanto, analisaram-se pinturas e fotografias de artefatos referentes a cada momento histórico estudado. Isso se deu a partir do método de revisão bibliográfica e metodologias de análise de imagens; atentando-se às diferentes tonalidades que a cor azul pode adquirir em cada meio de reprodução. Começa-se pela Antiguidade, com o lápis-lazúli, azul egípcio e índigo. Já na Idade Média, essa coloração adquiriu um significado religioso e nobre. Porém, na Idade Moderna o azul ganhou diversos significados e tonalidades, passando pelos principais períodos: Renascimento, Barroco e Rococó. Já na Idade Contemporânea, com a invenção e popularização dos corantes sintéticos, essa cor pôde ser aplicada de formas completamente novas. Esse artigo também reflete sobre os dogmas que associam o azul aos meninos, e a origem dessas ideias no período da Segunda Guerra Mundial. Assim, o estudo aqui realizado constrói um conhecimento singular e específico; que discorre acerca dos diferentes significados e formas de aplicação que a cor azul adquiriu na indumentária da população ocidental ao longo da história.

Palavras-chaves: Azul, História da Moda, Indumentária, Ocidente.

* Autores: Ana Júlia Neres Bariani (anaju_baris@usp.br); Anna Gabriela Seiko Ferraz Taguchi (annataguchi@usp.br); Beatriz Nogueira Alves (beatriznogueira@usp.br); Leandro Arcanjo Ferreira da Silva (leandro.arcanjo@usp.br); e Thaís Malta dos Santos (thaismalta@usp.br). Alunos do curso de Bacharelado em Têxtil e Moda da Escola de Artes, Ciências e Humanidades da USP. 


\section{artigos}

\section{O Azul na História da Moda}

\section{Introdução}

Segundo Pastoureau (1997 apud. SILVEIRA, 2015, p. 123), a cor azul é a preferida de mais da metade da população ocidental. Atribui-se a ela significado infinito e longínquo, e ao mesmo tempo frieza ou paz (SILVEIRA, 2015, p.123).

Além disso, uma pesquisa realizada pela YouGov constatou que em dez países, localizados em quatro continentes, a cor azul é a preferida da população; como mostra a Imagem 1:

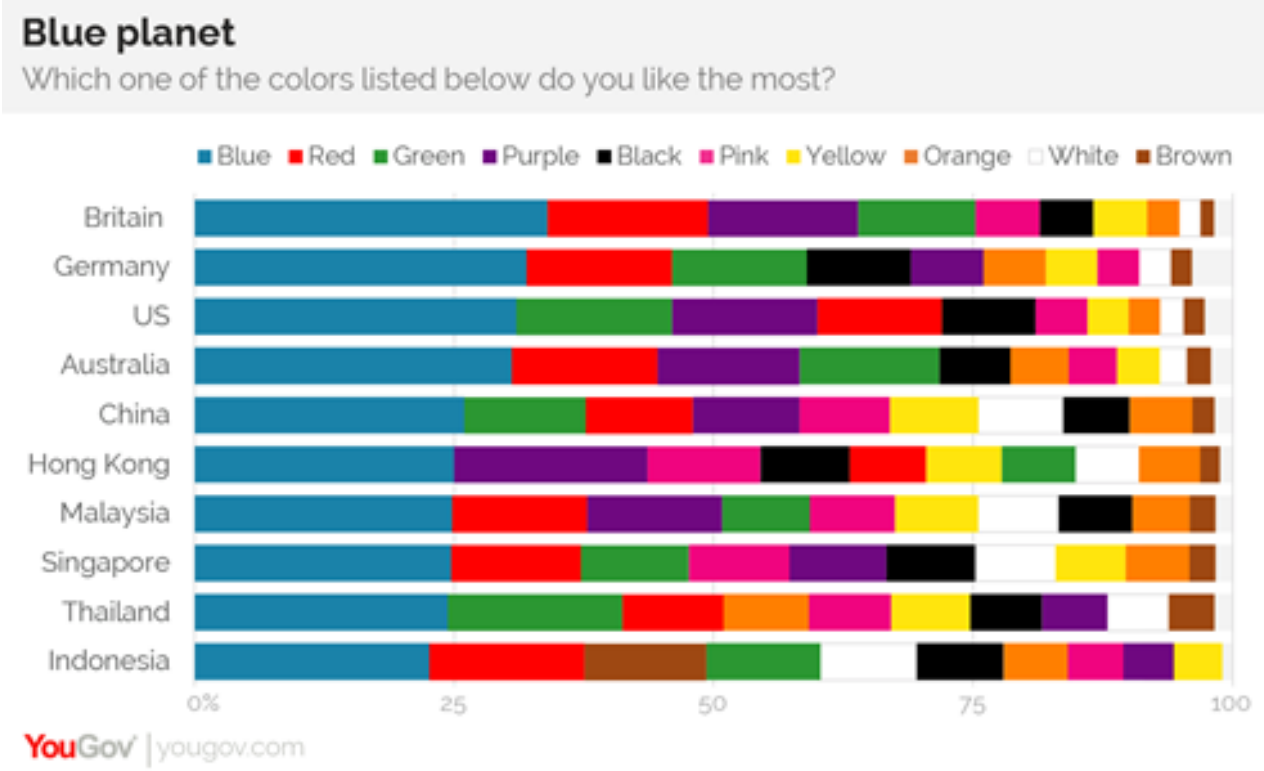

Imagem 1: Pesquisa de preferência de cores (Jordan, 2019).

Apesar disso, observam-se poucas pesquisas não só do azul, mas das cores de uma forma geral, como segmento de estudo da indumentária. Nesse sentido, o presente projeto pretende contribuir com o conhecimento acerca do uso do azul na moda ocidental, visto que as cores do vestuário ao longo das décadas possuem premissas sociais, culturais, políticas e comportamentais, sendo essencial o estudo delas para a compreensão da história da humanidade. 


\section{artigos}

Ana Júlia Bariani, Anna Gabriela Taguchi, Beatriz Alves, Leandro Silva, Thais Santos

\section{Objetivos}

\section{Objetivo Geral}

Investigar o uso da cor azul na indumentária dos diferentes períodos históricos com foco nas sociedades ocidentais.

\section{Objetivos Específicos}

a. Traçar uma linha do tempo constando os principais períodos históricos do ocidente e a recorrência da cor azul na indumentária de cada um deles;

b. Retratar o surgimento e a utilização dos diferentes pigmentos de azul na indumentária de cada período histórico;

c. Abordar o significado do azul em cada época e suas respectivas alterações;

d. Investigar o uso do azul na indumentária a partir de suas representações em artes visuais;

e. Estudar as influências sociais no uso da cor azul de acordo com os gêneros na contemporaneidade.

\section{Metodologia}

\section{Revisão bibliográfica}

Neste estudo adotou-se como estratégia metodológica a revisão bibliográfica descrita pela (UNESP, 2015, p. 2). Esse 


\section{artigos}

\section{O Azul na História da Moda}

lógica dos estudos sobre um determinado tópico. A combinação de pesquisas com diferentes métodos combinados na revisão integrativa amplia as possibilidades de análise da literatura." (UNESP, 2015, p. 2)

Além disso, a revisão bibliográfica oferece meios que auxiliam na definição e resolução dos problemas já conhecidos, como também permite explorar novas áreas onde os mesmos ainda não se cristalizaram suficientemente (CAMPELO, 2013, p. 15). A autora ressalta que esse tipo de método permite a cobertura de uma gama de fenômenos muito mais ampla, principalmente quando o problema da pesquisa requer a coleta de dados muito dispersos no espaço.

Nesta linha de pensamento, Andrade (1997, p. 30) afirma que uma pesquisa bibliográfica pode ser desenvolvida como um trabalho em si mesmo ou constituir-se numa etapa de elaboração de monografias, dissertações, etc.

\section{Análise de Imagens}

Para amparar o levantamento bibliográfico realizou-se também a metodologia de Análise de imagem. Segundo Iluska Coutinho (2009):

O termo imagem remete ao latim imago, cujo sentido é o de toda e qualquer visualização gerada pelo ser humano, seja em forma de objeto, de obra de de arte, de registro fotomecânico, de construção pictórica (pintura, desenho, gravura) ou até de pensamento (imagens mentais). (p.331)

Foram selecionadas diversas artes visuais, em razão de suas relações cromáticas (cores que se opõem e/ou se relacionam na linguagem da moda), a fim de exemplificar visualmente os usos da cor azul na indumentária em diferentes períodos na moda ocidental.

A importância da Análise de Imagem poderia ainda ser avaliada pelo espaço ocupado pelos registros visuais na vida em sociedade, ou melhor, no próprio 


\section{artigos}

\section{Ana Júlia Bariani, Anna Gabriela Taguchi, Beatriz Alves, Leandro Silva, Thais Santos}

reconhecimento das origens do homem [...] Do mito da caverna à Bíblia, aprendemos que nós somos imagens, seres que se parecem com o Belo, o Bom e o Sagrado. (JOLY, 1996, p.16 apud, COUTINHO, 2009 p.331.).

Nesse sentido, a leitura e interpretação de figuras através de uma sequência conexa permite criar analogias entre elas. Tais analogias são possíveis de serem detectadas devido ao pré-conhecimento ou reconhecimento do processo cultural em que a imagem foi produzida (VICENTE, 2008, p. 148).

Ao analisar figuras históricas, identifica-se uma espécie de semelhança. Assim, estão presentes duas formas de tempo: o presente (que reflete sobre as possibilidades materiais da imagem) e os desdobramentos da era em que se produziu a imagem, ao passo que se criam as ideias de história, passado e tradição (NEIVA, 1993).

Assim, Vicente (2008, p. 153-157) destaca alguns conceitos a se considerar na análise de imagens. São eles: condições da análise; história causal; informação incorporada; intenções do autor; construção do objeto. As condições da análise referem-se aos meios utilizados para representação visual, que viabilizam a leitura da figura. A história causal diz respeito ao meio de produção das imagens. A informação incorporada trata sobre a quantidade e qualidade da informação presente no registro imagético que será analisado. As intenções do autor abordam o motivo ou ponto de vista do produtor da figura. A construção do objeto de estudo se refere à interpretação da imagem a partir de uma metodologia adequada relacionada a um projeto; assim como a escolha de conceitos e teorias norteadoras das conclusões.

\section{O Azul na Indumentária da Antiguidade}

Nas sociedades gregas e egípcias da antiguidade já se fazia o uso de maquiagens e adornos corporais (LIPOVETSKY, 1987). Para tanto, buscavam-se diferentes 


\section{artigos}

\section{O Azul na História da Moda}

formas de extrair pigmentos. Os seres humanos ancestrais fizeram grandes descobertas no mundo das cores, o qual eram extraídas de minerais coloridos e dos mais diferentes tons de terra.

Porém, o homem do Paleolítico não utilizava tons de azul, e sim, vermelho, ocre, marrom e preto em suas pinturas rupestres. Somente no Neolítico, quando a humanidade se tornou sedentária, diversas técnicas de coloração foram aprimoradas, o que permitiu o surgimento dos primeiros indícios do uso da cor azul entre as civilizações. (CAMPBELL, 2013 apud FERREIRA, 2011, p. 23).

\section{Lápis Lazúli}

O lápis-lazúli é uma pedra semipreciosa que foi extraída no Afeganistão por mais de três mil anos, sendo exportado para todas as partes do mundo antigo. No Irã e na Mesopotâmia era utilizada para fazer jóias e vasos. No Egito, utilizou-se nas sobrancelhas da máscara fúnebre do rei Tutancâmon (1341-1323 a.C.) (CALANDRINI, 2018, p.20). A importação do lápis-lazúli por caravana através do deserto do Afeganistão para Egito era muito cara, desse modo, os egípcios começaram a produzir seu próprio pigmento surgindo, assim, o azul egípcio (CAMPBELL, 2013 p. 26). 


\section{artigos}

Ana Júlia Bariani, Anna Gabriela Taguchi, Beatriz Alves, Leandro Silva, Thais Santos

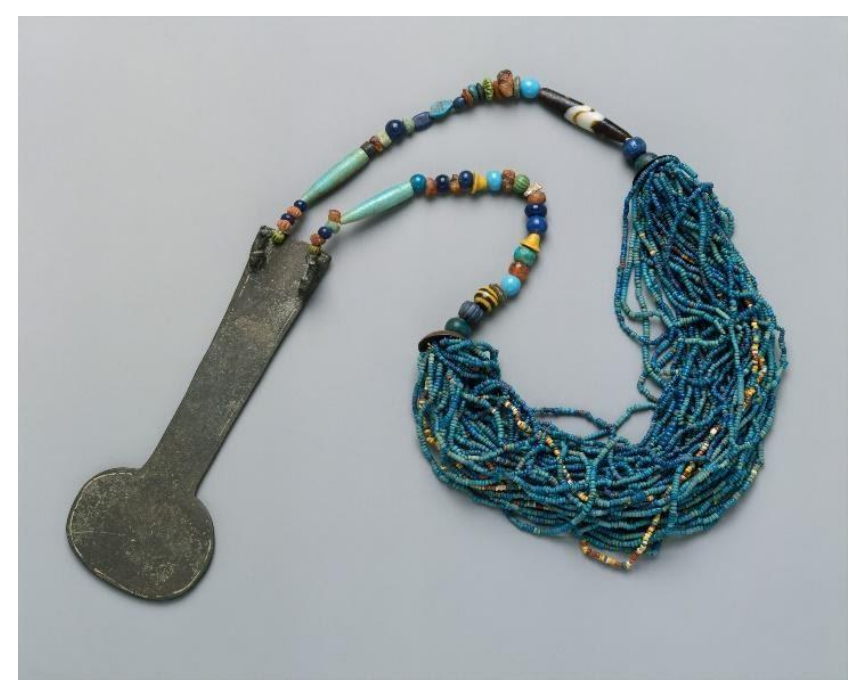

Imagem 2: Colar Menat de Malqata, 1390-1353 a.C. (Metropolitan Museum of Art)

\section{Azul egípcio}

Apesar da origem do pigmento azul ser incerta, estudos atuais mostram que por volta de 3000 a.C., os egípcios criaram a primeira manipulação sintética de pigmento denominado azul egípcio, o qual era obtido na sua forma natural ou a partir da combinação de um composto de cálcio com óxido de cobre e areia.

O azul egípcio foi utilizado, particularmente, em estátuas fúnebres e pinturas de tumbas. O azul era considerado uma cor benéfica que protegeria os mortos contra o mal na vida após a morte, dessa forma, era utilizado, por exemplo, nas sobranceIhas da máscara fúnebre do rei Tutancâmon (1341-1323 a.C.). O corante azul também foi usado para colorir o pano no qual as múmias eram enroladas (CAMPBELL, 2013 p. 24).

A cor azul para algumas das civilizações antigas representava poder social e vestia membros da realeza, e também possuía como significado o eterno e o infinito, sendo associado a água e ao rio Nilo (CORRÊA, 2017, p. 13). Outra visão da simbologia 


\section{artigos}

\section{O Azul na História da Moda}

é dada por Calandrini (2018, p. 20), a qual o azul estava associado ao céu e à divindade, dessa forma, o deus egípcio Amun poderia tornar sua pele azul para que ele pudesse voar, invisível, através do céu. O uso dessa cor também poderia proteger contra o mal, como é visto na Imagem 3, o objeto mumiforme de Shabti que está na tumba de Yuya e Tjuyu no Vale dos Reis em Tebas, foi pintada com azul egípcio, e tem como função de substituir o espírito em quaisquer tarefas obrigatórias que ele é chamado a realizar na vida após a morte.

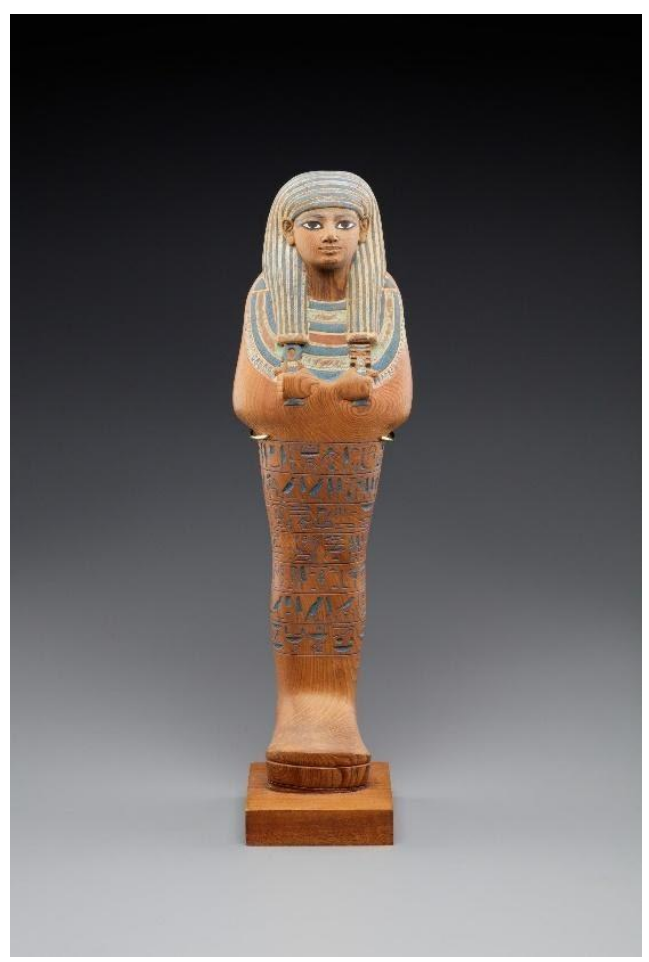

Imagem 3: Shabti de Yuya 1390-1352 a.C. (Metropolitan Museum of Art)

Ainda assim, o azul egípcio é encontrado em numerosos objetos gregos e romanos, incluindo estátuas do Parthenon de Atenas e pinturas murais de Pompéia. Apesar da ampla aplicação na arte, o azul egípcio deixou de ser usado, e seu método 


\section{artigos}

\section{Ana Júlia Bariani, Anna Gabriela Taguchi, Beatriz Alves, Leandro Silva, Thais Santos}

de produção caiu no esquecimento quando a era romana chegou ao fim (CORRÊA, 2017, p. 22).

\section{Índigo}

Apesar da origem do índigo ser incerta, em manuscritos Atharvaveda, escrituras Brâmanes que datam 4 mil anos a.C., e no texto budista Samyutta Nikaya, escritos a 3 mil anos a.C., aparecem menções ao índigo como tintura (CAMPBELL, 2013 apud FERREIRA, 2011, p. 23). Dessa forma, a partir da divisão quadripartite da história geral do estudo de José Farias Junior (2019), o surgimento do índigo se dá antes da invenção da escrita que está datada em 4.000 a.C.

O índigo, também conhecido por anil, é um dos corantes azuis mais antigos a ser usado pelo homem, já que possui rapidez no tingimento e ótima absorção por fibras vegetais e animais. As plantas índigo são originárias de diversas partes do mundo e possuem diferentes espécies (CAMPBELL, 2013 p. 33).

\footnotetext{
Algumas peças de roupas tingidas foram encontradas nas escavações de Tebas, datadas de 1000 a.C., indicavam terem sido pintadas de woad, um tipo de anil proveniente da espécie de planta Isatis tinctoria L. que produz um tom de azul um pouco mais esverdeado que o índigo oriental (Persicaria tinctoria Ait.) e apresenta menor potencial tintoria. (CAMPBELL, 2013, p. 25)
}

A Imagem 4 apresenta um lenço azul tingido de índigo encontrado no Baú de Tutancâmon no Vale dos Reis em Tebas, essa imagem mostra como o pigmento pode ter surgido muito antes de outras formas de tingimento. 


\section{artigos}

\section{O Azul na História da Moda}

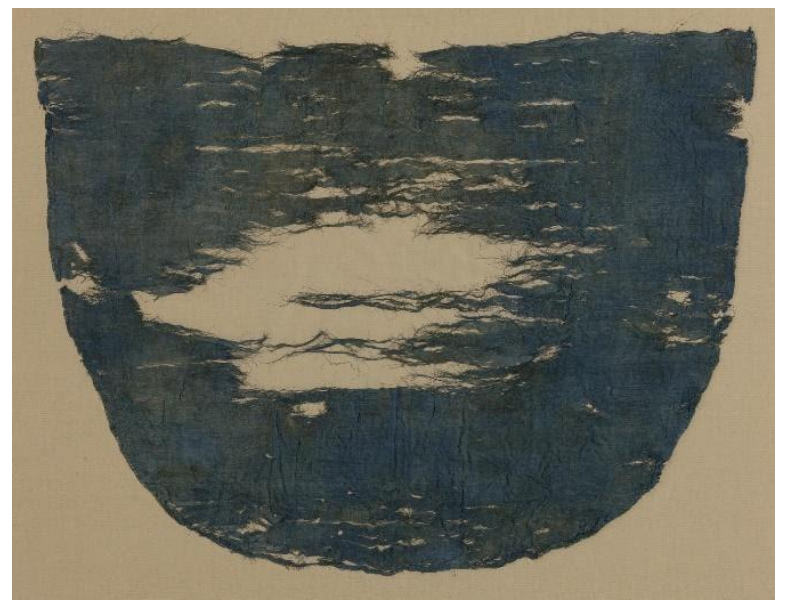

Imagem 4: Lenço azul do esconderijo de embalsamamento de Tutankhamon 1336-1327 a.C. (Metropolitan Museum of Art)

Na Grécia, ao contrário do povo oriental e asiático, o azul era muito pouco valorizado e utilizado (CALANDRINI, 2018, p. 20). De acordo com Campbell (2013, p. 26), os gregos antigos classificavam as cores por serem mais claras ou escuras do que por seu matiz, assim, não possuíam uma palavra que expressasse unicamente o termo "azul". A palavra grega para azul escuro era kyaneos, que também poderia significar verde escuro, violeta, preto ou marrom. Já para azul claro era glaukos, que poderia representar verde claro, cinza ou amarelo. Os gregos importaram corante índigo da Índia, chamando-o, por isso, de indikon.

Os romanos também importavam índigo. Para eles, o azul era a cor da roupa da classe trabalhadora, enquanto os nobres e ricos usavam branco, preto, vermelho ou violeta. Dessa forma, a cor da vestimenta tornara-se um forte índice de definição de classe, tal como descrito por Pierre Bourdieu (2006, p. 97).

O azul era considerado a cor dos bárbaros, que é justificada por registros que contam que os celtas e os germanos pintavam seus corpos de azul para aterrorizar seus adversários, possivelmente utilizavam anil para essas pinturas. A partir de 500 


\section{artigos}

Ana Júlia Bariani, Anna Gabriela Taguchi, Beatriz Alves, Leandro Silva, Thais Santos

a.C., na época da República, início do Império Romano, o azul tinha como simbologia o luto e a morte, sendo ligada ao submundo. Essa impressão negativa do azul extrapola as vestimentas, e os habitantes do império consideravam os olhos azuis uma espécie de deformidade física, muito usada para descrever monstros assustadores e pessoas muito feias na literatura da época (CAMPBELL, 2013, p. 26). O azul toma diferente simbologia e papel comercial, quando ocorre a queda do Império Romano do Ocidente em 476 d.C., de acordo com José Farias Junior (2019, p. 15), entrando em uma nova fase na Idade Média.

\section{O azul na indumentária da Idade Média (476-1453 d.C.)}

\section{Contextualização}

A Idade Média, segundo a divisão estabelecida no estudo de José Farias Júnior (2019, p. 15), consiste no período entre 476 a 1453 d.C. A época pode ser caracterizada por apresentar uma sociedade estamental repleta de sistemas e signos, cujo principal suporte se encontrava na vestimenta.

Assim, devido a tal importância dada ao traje, a composição de cada aspecto seu carregava consigo um significado, podendo, por exemplo, o uso de um determinado tecido ou de uma cor específica representar a posição de um indivíduo na hierarquia social (PASTOUREAU, 1999 apud BRANDÃO, 2017, p. 45). Assim, a indumentária torna-se uma modalidade de representação social, descrita por Roger Chartier (1991, p. 183); como uma forma institucionalizada e objetivada de representantes de uma classe social se destacarem das demais.

Nesse sentido, um registro que coloca em evidência o status quo atrelado à vestimenta no período é a consolidação das leis suntuárias (RIELLO, 2012 apud BRAN- 


\section{artigos}

\section{O Azul na História da Moda}

DÃO, 2017, p. 47). Essas leis apresentavam um caráter proibitivo que, além de apresentarem um viés político, social e econômico, detinham como propósito fazer restrições à indumentária de certas pessoas, com três motivações de destaque, sendo elas "reforçar hierarquias, privilégios e posições sociais; efeito moralizador relacionado ao luxo de acordo com diferentes camadas sociais; e protecionismo econômico, relacionado ao uso de tecidos, pedras preciosas e materiais diversos" (BON, 2018, p. 3).

Ainda sobre a indumentária na Idade Média pode-se afirmar que seu custo era extremamente elevado, devido ao fato de cada peça ser feita exclusivamente para cada pessoa. Em adição, apesar de o tecido grande parte das vezes ser confeccionado em casa, o tingimento era realizado em ateliês especializados, circunstância que agregava ainda maior valor monetário ao produto final e justifica o porquê de grande parte das roupas da população apresentarem as cores naturais das fibras que compõem os tecidos (RIELLO, 2012 apud BRANDÃO, 2017, p. 46).

\section{Simbologia}

Ao trazer o cenário descrito a respeito da Idade Média para o contexto da temática do azul, pode-se sustentar que a cor passou a realmente ser valorizada durante esse período. Um de seus precursores foi o Rei da França, Luís VI, que ao final do século XII instituiu o azul como a cor componente dos uniformes de seu exército, representando uma forma de homenagem à Virgem Maria, padroeira do Estado. Desse modo, com a crescente notoriedade na monarquia francesa, o pigmento passou a ser reconhecido como um símbolo da realeza e da magnificência, e começou a ser adotado pela aristocracia como um todo. Entretanto, isso somente foi possível com o aperfeiçoamento das técnicas de tingimento que envolviam a cor, permitindo a aparição 


\section{artigos}

Ana Júlia Bariani, Anna Gabriela Taguchi, Beatriz Alves, Leandro Silva, Thais Santos

de tons mais marcantes e brilhantes (PASTOUREAU, 2001 apud CAMPBELL, 2013, p. 29).

Além disso, é importante ressaltar a influência da Virgem Maria na determinação do uso do pigmento. Por meio de suas representações utilizando peças azuis, para simbolizar "amor, fé fidelidade e humildade", a cor passou a ter maior relevância, seja nas artes ou na indumentária (PASTOUREAU, 2000 apud PEREIRA, 2011, p. 102). A Imagem 5 demonstra um retrato da Virgem em seu trono segurando o menino Jesus, no primeiro mosaico da fase iconoclasta da Basílica de Hagia Sophia, datando do século IX (HAGIA SOPHIA MUSEUM, [s.d.]). A partir do que foi observado através de fontes digitais, é possível ponderar que a peça utilizada por Maria é azul, evidenciando um dos primeiros indícios do uso do pigmento nas artes visuais, que resultaria posteriormente na sua adoção em grande escala. Ademais, como a cor não estava registrada no sistema litúrgico católico, ela não foi de grande importância somente para os seguidores dessa religião, mas também para os protestantes, que a relacionavam à moralidade (PASTOUREAU, 2000 apud PEREIRA, 2011, p. 102). 


\section{artigos}

O Azul na História da Moda

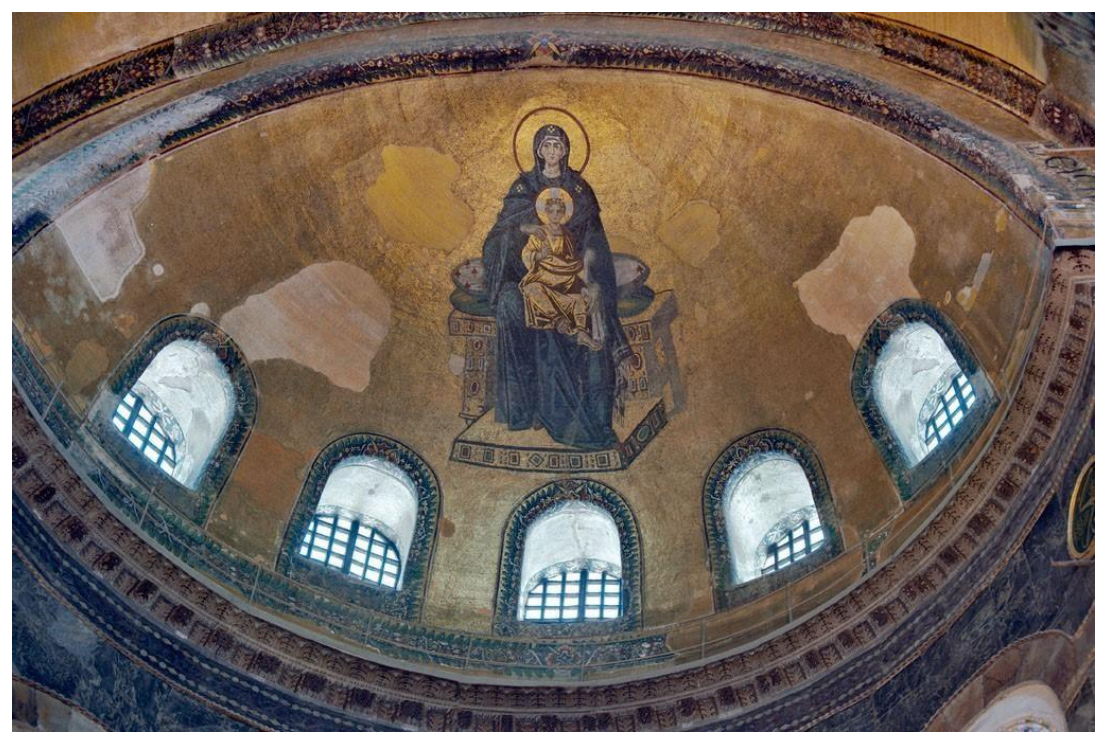

Imagem 5: Mosaico da Abside (Hagia Sophia Museum)

Entretanto, o azul sofreu certa resistência na Alemanha e na Itália, em que se perpetuava o vermelho como a cor do imperador. Desse modo, atitudes como subornar vidraceiros para representar o diabo de azul nos vitrais e ilustrar constantemente em afrescos o inferno no mesmo pigmento, tentaram retardar seu avanço (PASTOUREAU, 2001 apud CAMPBELL, 2013, p. 29). Contudo, tais tentativas foram falhas, levando ao sucesso geral do azul no final da Idade Média, considerado por Pastoureau (2006 apud CORRÊA, 2017, p. 27) a cor da monarquia e da aristocracia.

\section{Obtenção do pigmento azul}

Apesar do índigo ser o corante mais conhecido para tingir peças em tons de azul, foi somente ao final da Idade Média que ele se consolidou no continente europeu. Nesse sentido, a planta pastel-dos-tintureiros era a única fonte do pigmento no ocidente (BALFOUR, 1998 apud SERRANO, LOPES, SERUYA, 2007, p. 17). 


\section{artigos}

Ana Júlia Bariani, Anna Gabriela Taguchi, Beatriz Alves, Leandro Silva, Thais Santos

Entretanto, com a expansão marítima-comercial européia ao final da Idade Média e início da Idade Moderna, o índigo passou a ser de conhecimento dos Estados europeus, principalmente daqueles responsáveis pelas navegações, ou seja, Portugal e Holanda (ARSENAULT et al., 2008, p. 70). Originado principalmente das Índias, o corante citado facilmente substituiu o pastel-dos-tintureiros por apresentar a vantagem de ser três vezes mais concentrado, possibilitando dessa forma sua prevalência e desenvolvimento durante a Idade Moderna (FIADEIRO, 1993, p. 13).

\section{O azul na moda da Idade Moderna (1453-1789)}

Com o final da Idade Média, caiu também o Teocentrismo presente na cultura européia. Esse cedeu protagonismo ao antropocentrismo e à racionalização a partir de meados do século XV, quando se deu início à Idade Moderna (PEZZOLO, 2013, p. 21). Assim, a cor azul sofreria alterações, deixando de estar presente apenas no manto da Virgem Maria.

\section{Renascimento}

Os ideais Renascentistas caracterizavam-se principalmente pela revalorização do estilo clássico greco-romano (CARVALHO, p. 12). As cortes da Europa colocavam suas peculiaridades em sua indumentária, do mesmo modo que influenciavam umas às outras (CARVALHO, 2009, p. 35).

\section{Inglaterra}

Diferente do que foi apontado por Pastoureau (2006 apud CORRÊA, 2017, p. 27), na Inglaterra pós Idade Média (século XIV), a cor azul é, na literatura local, associada à indumentária de grupos menos abastados (VIEIRA, 2012, p. 32). Essa cor aparece retratada nos trajes de indivíduos pertencentes à classe de camponeses. 


\section{artigos}

\section{O Azul na História da Moda}

Já na era de Elizabeth I, o azul continuava não sendo presente no vestuário da nobreza (ALBUQUERQUE, 2015, p. 4). Os rufos (que alcançaram seu auge no reinado Elizabethano) eram tingidos de várias formas, também de azul. Porém, em certo ponto a rainha proibiu o uso de rufos azuis, devido à cor estar presente na bandeira da Escócia, país rival da Inglaterra (ALBUQUERQUE, 2015, p. 4).

\section{Itália}

Na Itália Renascentista a roupa também agia como indicador do status social e econômico do indivíduo (EVELIN, 2012). Pessoas de classes sociais mais abastadas encomendavam retratos aos pintores como demonstração de poder. Ademais, a cor azul apresenta destaque na joalheria feminina; se fazendo presente nas safiras, tal como mostrado na Imagem 6:

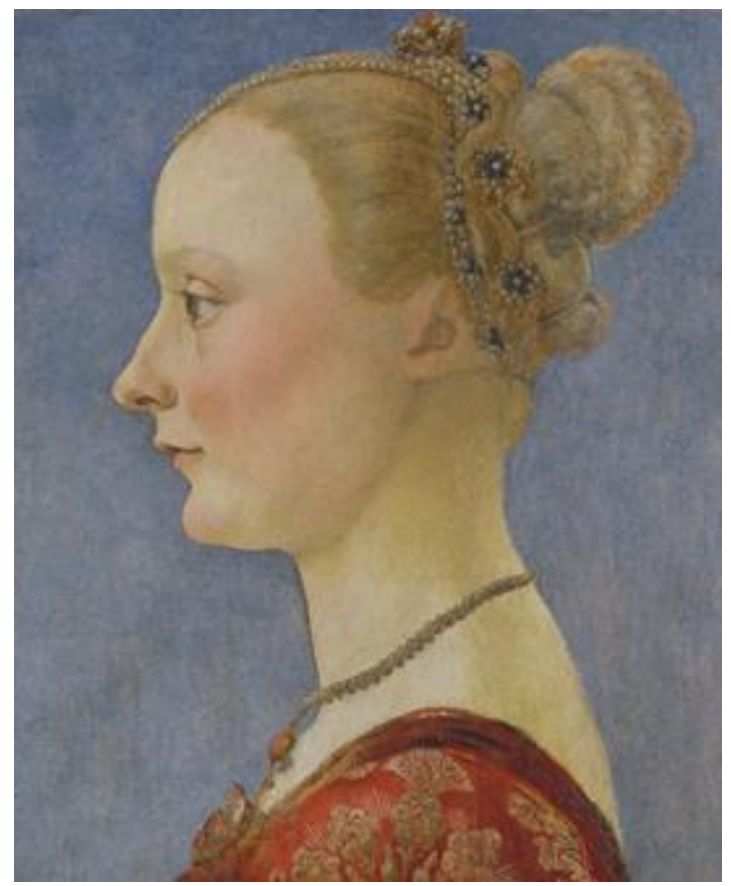

Imagem 6: Portrait of a Woman (Piero del Pollaiuolo) -1480 (Metropolitan Museum) 


\section{artigos}

Ana Júlia Bariani, Anna Gabriela Taguchi, Beatriz Alves, Leandro Silva, Thais Santos

\section{Barroco}

Esse período é compreendido no século XVII (CARVALHO, 2009, p. 46). Nessa mesma época, sob a regência de Luís XIV (o Rei Sol), a França se impôs como "ditadora de moda" (PEZZOLO, 2013, p. 21).

O manto real de Luís XIV demonstra como a cor azul era aplicada na indumentária da sua corte. Essa cor é citada por (FRASQUETE, 2014, p. 6) e (LÓPEZ, 2017, p. 3) como azul real, e é claramente percebido por um de seus retratos, mostrado na Imagem 7:

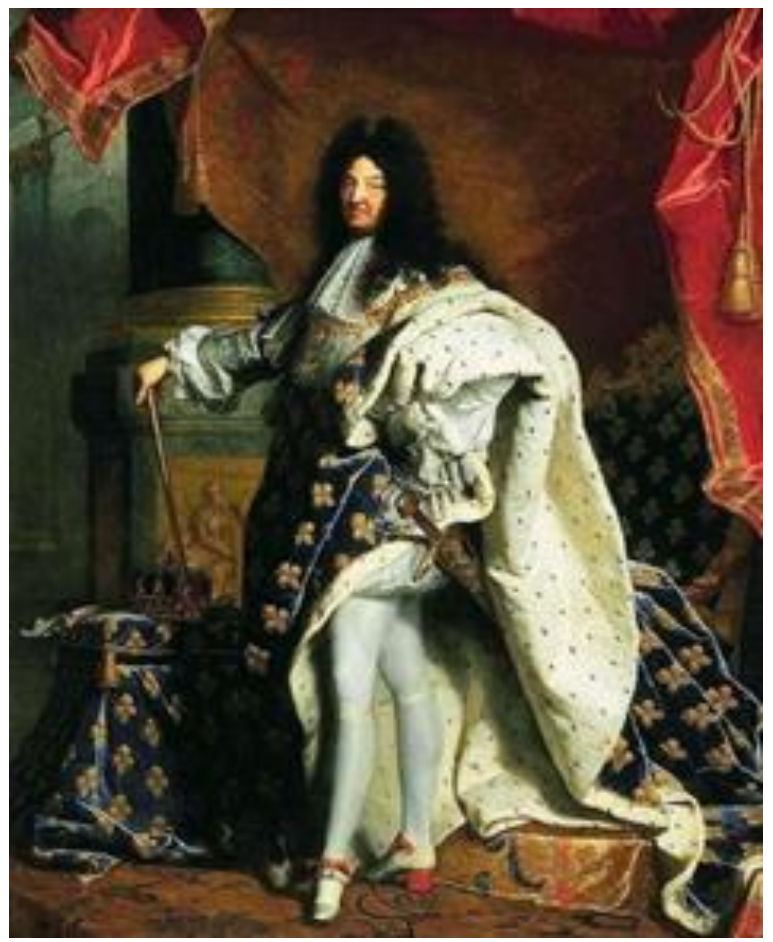

Imagem 7: Retrato de luís XIV, de Hyacinthe Rigaud (Louvre Museum)

No manto do monarca,

“o azul parece estar distante de nós, mas que gostamos de contemplá-lo, 'não porque ele avance em nossa direção, mas por nos incitar a persegui-lo'. Essa ideia transmitida pela cor, unida a outros elementos visuais de vestuário, como 


\section{artigos}

\section{O Azul na História da Moda}

o excesso de tecido, ao qual Luís como rei tinha acesso, evidenciavam a posição real e ainda reafirmavam seu poder." (FRASQUETE, 2014, p. 6).

Na indumentária da corte do Rei Sol, o azul ainda se fazia presente nos casacos de seus cortesãos favoritos (LÓPEZ, 2017, p. 33). Tais peças eram de cor azul, forrada a vermelho, bordadas a ouro e prata. Além disso, o uso desses itens só poderia ser permitido por decreto expedido pelo rei. A Imagem 8 apresenta os cortesãos franceses acompanhando o monarca supremo nos jardins do Palácio de Versalhes, ato que por si só já conferia extremo privilégio. Porém, apenas três homens utilizam essas roupas, fato que confere honra máxima (LÓPEZ, 2017, p. 33).

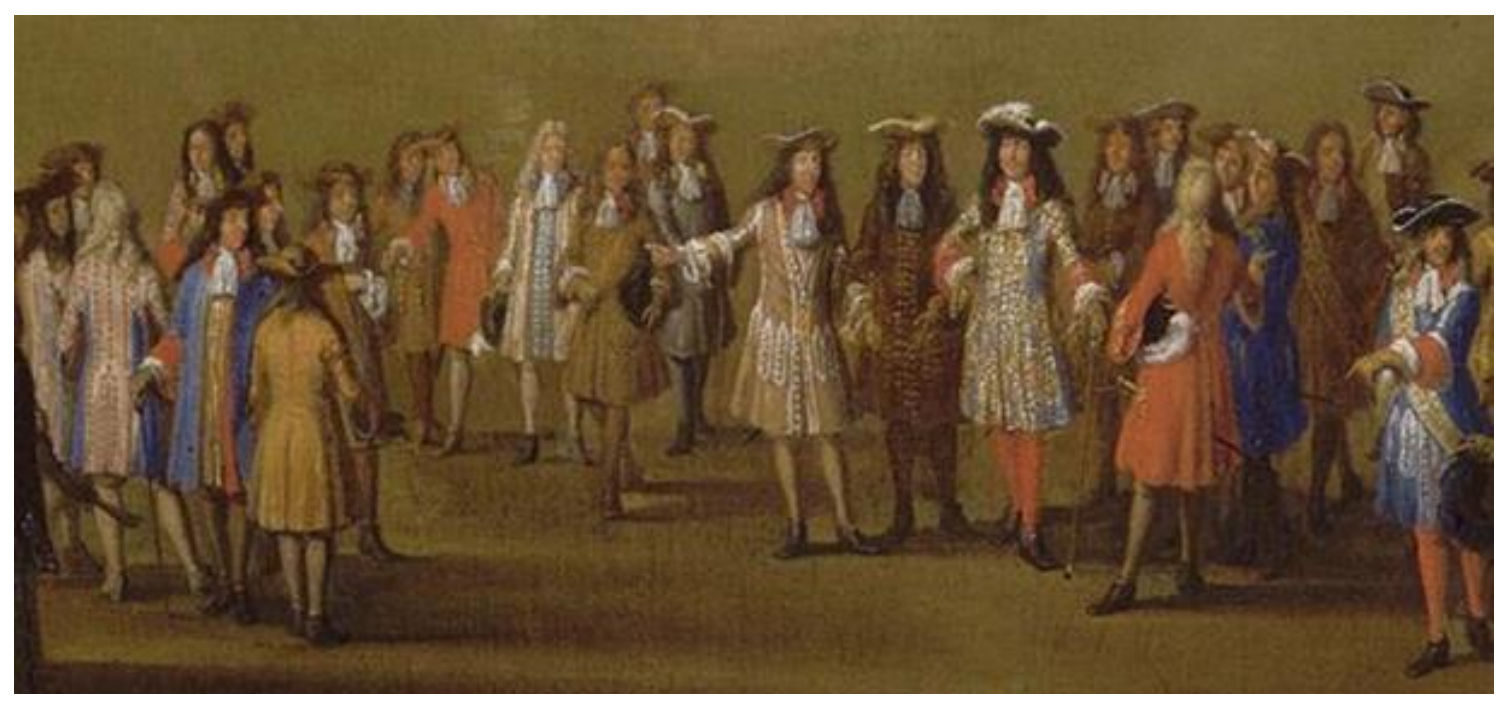

Imagem 8: Luís XIV andando pelos jardins de Versalhes, Étienne Allegrain, 1668 (López 2017)

\section{Rococó}

O período do Rococó se desenvolveu após a era do Barroco em diversas manifestações artísticas; tendo como seu principal berço a França, a partir de 1715, após a 


\section{artigos}

\section{Ana Júlia Bariani, Anna Gabriela Taguchi, Beatriz Alves, Leandro Silva, Thais Santos}

morte de Luís XIV (CARVALHO, p. 14). Esse estilo é um reflexo do comportamento da elite francesa de Paris e Versailles, a qual buscava traduzir a agradabilidade da vida.

Nesse sentido, colocou-se na moda vestimentas em cores mais claras e tons pálidos, sobretudo o azul pastel (MINISTERIO DE CULTURA; KYOTO COSTUME INSTITUTE, 2007, p. 44). Essas cores tomaram o protagonismo do vermelho intenso e turquesa antes visto no barroco. As texturas e os brilhos são valorizados em tonalidades claras de azul, dentre outras cores, como mostra o quadro A Toilette, apresentado na Imagem 9 (PEZZOLO, 2013, p. 22).

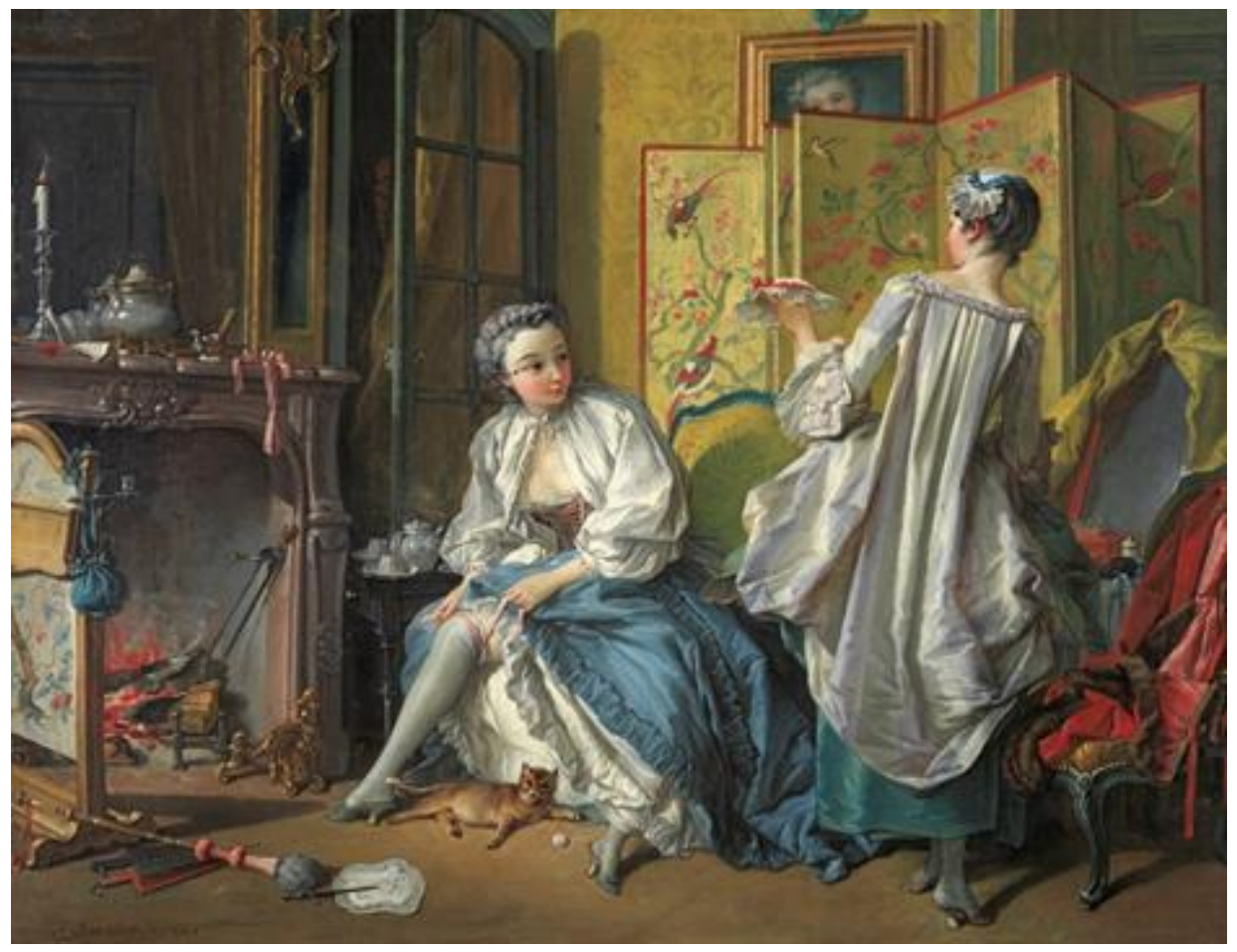

Imagem 9: A toilette (1742). Museo Thyssen-Bornemisza, Madri (Thyssen-Bornemisza Museo)

"A ascensão do azul também poderia estar relacionada com o uso do índigo a larga escala e, posteriormente no início do século XVIII, com o descobrimento acidental do azul da Prússia, pelo alemão Diesbach (Ball, 2001, p.273). O azul conquistou cada vez mais espaço na sociedade ocidental e tornou-se numa cor da moda, aristocrática e era referida em textos literários como a cor da alegria, do amor, da lealdade e da paz." (RIBEIRO, 2016, p. 22) 


\section{artigos}

\section{O Azul na História da Moda}

Já no ano de 1774 sobe ao trono o rei Luís XVI ao lado de Maria Antonieta, que se torna rainha da França e um ícone feminino de excessos (CARVALHO, 2009, p. 55). Porém, o Rococó chega ao fim com a Revolução Francesa, em que Luís XIV e sua esposa são decapitados em praça pública.

\section{Pigmentos azuis na Idade Moderna}

\section{Índigo}

Com a preferência do índigo sobre o pastel-dos-tintureiros, produtores locais viram essa especiaria como uma ameaça, já que produzia azuis mais profundos e mais rápidos. Então, alguns países proibiram a sua comercialização, a fim de proteger o comércio local (ARSENAULT, ROSE, et al., 2008, p. 71).

Arsenault, Rose, et al. (2008, p. 72) seguem dizendo que tais medidas não foram suficientes para parar o fluxo de Índigo na Europa. E no final de 1600, esse corante já havia sido legalizado na maioria dos países. Fato que culminou em um aumento intenso da produção desse pigmento.

\section{Azul da Prússia}

No ano de 1704, Heinrich Diesbach, um fabricante de corantes acidentalmente sintetizou o primeiro pigmento sintético de coloração azul do mundo. Posteriormente, Diesbach e seu colega Johann Konrad Dippel se mudaram para Paris e começaram a produção desse pigmento com o nome de Azul Parisiense (BERNARDES, 2012, p. 35).

Porém, o pigmento ficou conhecido como Azul da Prússia por ter sido largamente utilizado na pintura dos uniformes militares prussianos (BERNARDES, 2012, p. 35). 


\title{
artigos
}

\author{
Ana Júlia Bariani, Anna Gabriela Taguchi, Beatriz Alves, Leandro Silva, Thais Santos \\ O azul na moda da Idade Contemporânea (1789 - Atualmente)
}

\section{A Revolução Francesa}

A Idade Contemporânea, segundo algumas divisões históricas ocidentais, tem como marco inicial a queda da bastilha e a Revolução Francesa, que se inicia em um contexto de crise política e econômica agravada por levantes camponeses os quais culminam na queda da monarquia e no estabelecimento da Primeira República Francesa em 1792 (GLOBOLIVROS, 2017, p. 209).

Diante da nova realidade, a indumentária e, principalmente, as cores usadas no vestuário sofrem enormes modificações, não apenas na França, como também em toda a Europa (BOUCHER, 2012, p. 310). Segundo François Boucher (2012, p. 311) “A queda do regime político francês e o fim da vida de corte acarretaram a supressão de todo 'traje de corte' até seu restabelecimento por Napoleão". Nesse sentido, as roupas tornam-se mais simples acrescidas de uma ausência na coloração, o que tem como objetivo opor-se às exuberâncias do antigo regime e ressaltar o lema da revolução que tem como princípio a liberdade (MINISTERIO DE CULTURA; KYOTO COSTUME INSTITUTE, 2007, p. 44).

Com o fim do "Reino do Terror" implantado na era republicana e a ascensão de Napoleão ao poder em 1799 (MARRIOT, 2015, p. 72), cria-se “um clima dominado pela necessidade de esquecer e o desejo de gozar a vida" (BOUCHER, 2012, p. 313). O estabelecimento de uma sociedade civil somado ao surgimento de uma nova classe burguesa com poder econômico e à descoberta da anilina mudam o vestuário do século XIX, tornando as cores deslumbrantes e mais vivas (MINISTERIO DE CULTURA; KYOTO COSTUME INSTITUTE, 2007, p. 23). As Imagens 10 e 11 apresentam vestidos datados do século XVIII e XIX respectivamente, a comparação entre as peças torna 


\section{artigos}

O Azul na História da Moda

nítido a diferença de saturação da cor azul nas duas épocas devido ao surgimento dos corantes sintéticos.

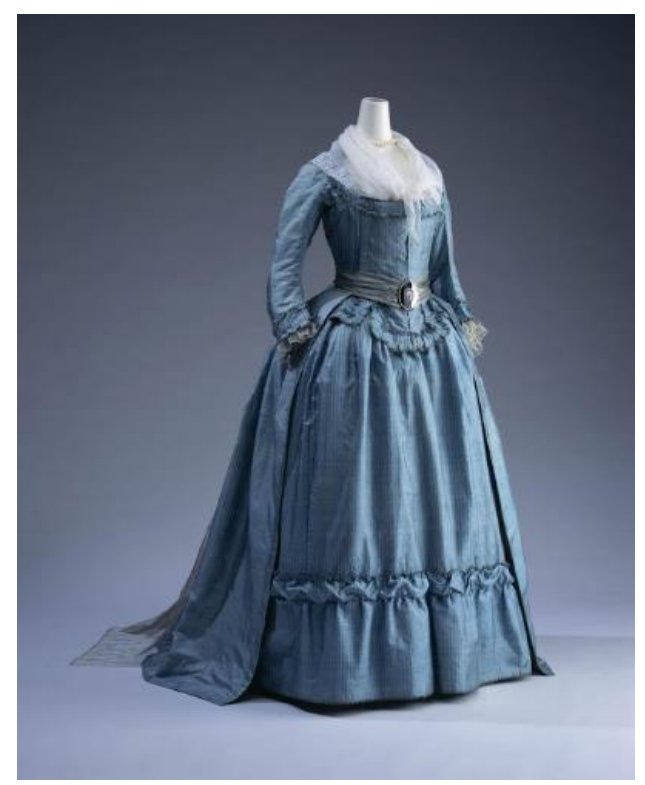

Imagem 10: “Vestido à Inglesa” em azul pastel, 1785, França (Ministerio de Cultura; Kyoto Costume Institute, 2007)

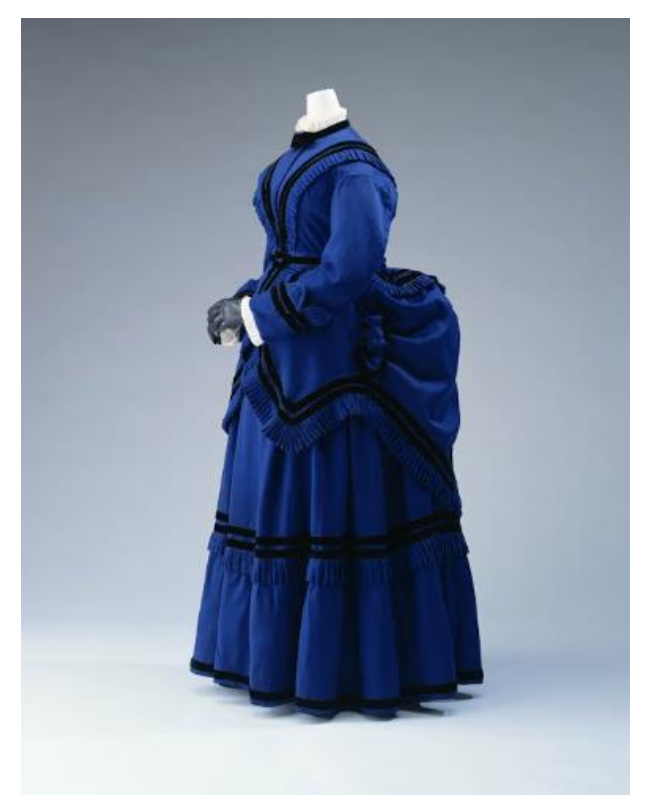

Imagem 11: “Vestido de dia” em azul vívido tingido com índigo sintético, 1875, Inglaterra (Ministerio de Cultura; Kyoto Costume Institute, 2007) 


\section{artigos}

Ana Júlia Bariani, Anna Gabriela Taguchi, Beatriz Alves, Leandro Silva, Thais Santos

\section{A descoberta da Anilina}

O século XIX mudou a relação da moda com as cores a partir do surgimento dos corantes sintéticos. Em 1856, um jovem de 18 anos chamado William Henry Perkin, descobre acidentalmente uma substância escura ao tentar encontrar um xarope para Malária (MINISTERIO DE CULTURA; KYOTO COSTUME INSTITUTE, 2007, p. 24). Tal descoberta torna o azul uma cor mais acessível, transformando seu significado dentro da sociedade ocidental (MAJOLO e VASQUES, 2013, p. 06).

\section{Uma nova simbologia}

Por muito tempo usado como referência para o divino, restrito a certas classes sociais devido à dificuldade de acesso às matérias-primas de seus pigmentos, o azul aparece na indumentária ocidental de meados do século XIX como uma cor já bastante democratizada.

Valdriana P. Corrêa (2017, p. 51) cita Michael Pastoureau (2010) que descreve as vestes de certa camada social da época: "Para as suas roupas, por exemplo, os camponeses mostravam um gosto especial por todos os tons de azul, gosto esse muitas vezes novo, que cortava com a moda dos pretos e cinzentos e dos castanhos dos séculos anteriores". Assim, associado a elementos do modo de vida camponês, a cor ganhou um novo significado; fenômeno descrito em Barthes (1978, p. 176).

Tal fator tem influência direta na arte produzida no momento. Em uma de suas cartas, Van Gogh menciona a beleza do azul colorido nas vestes das pessoas que o circundavam, deixando claro a influência das imagens cotidianas no uso dessa cor em suas obras (CORRÊA, 2017, p. 50-51 apud VAN GOGH, 2016 p. 129). Isso é visto na Imagem 12: 


\section{artigos}

O Azul na História da Moda

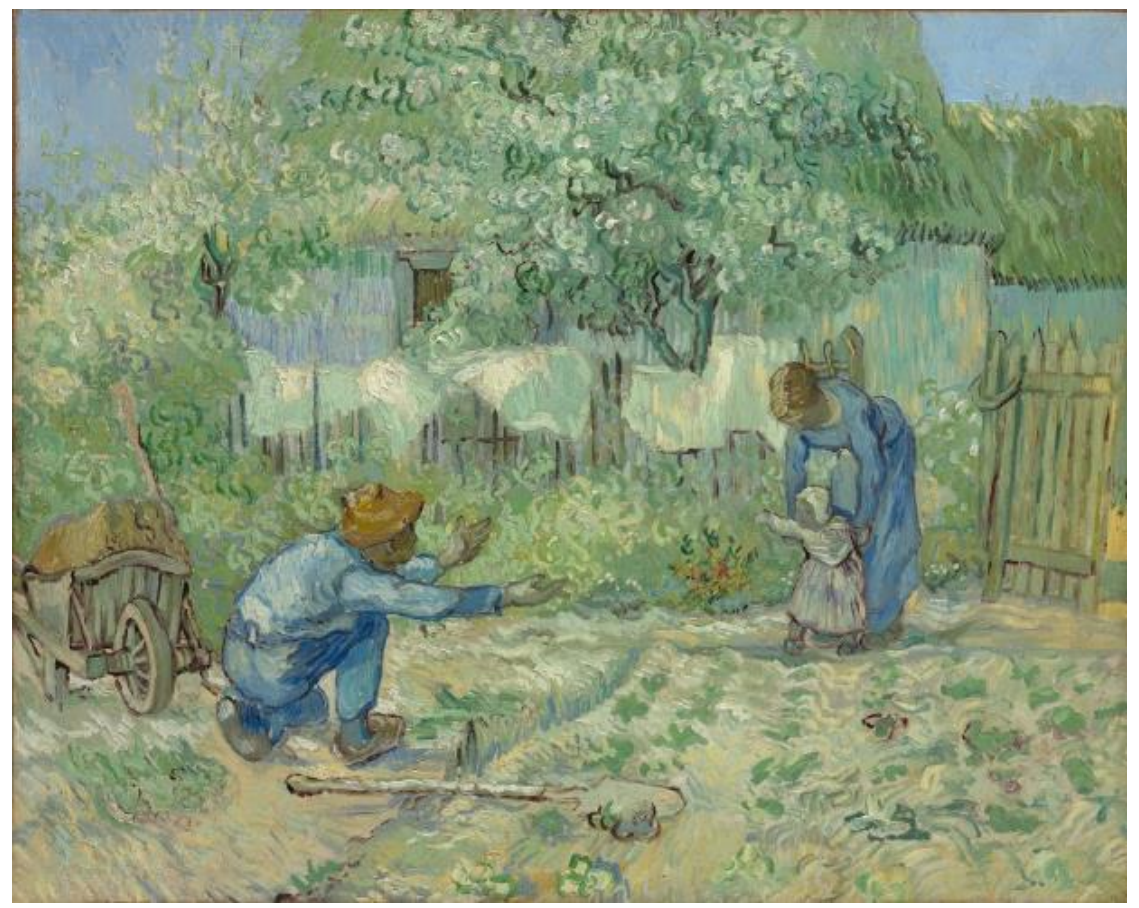

Imagem 12: "Primeiros Passos (depois de Millet)" de Vincent van Gogh, 1890 (The Metropolitan Museum of Art)

Nesse sentido, o azul abandona toda a simbologia religiosa e passa a expressar sentimentos e emoções. Na arte, essa cor é bastante utilizada por nomes como Caspar David Friedrich (1774-1840) para caracterizar uma ideia de melancolia e tristeza, assim como, por Picasso em sua chamada "fase azul", a qual o pintor utiliza-se da coloração para manifestar sentimentos como a dor (CORRÊA, 2017, p. 66). Isso é notado na Imagem 13. Além disso, a partir de uma visão contemporânea, Vânia C. G. Inácio (2010, p. 34 apud LASTRO, 2002) atribui outros significados à coloração afirmando que "o azul é caracterizado como uma cor que transmite segurança e conforto". 


\section{artigos}

Ana Júlia Bariani, Anna Gabriela Taguchi, Beatriz Alves, Leandro Silva, Thais Santos

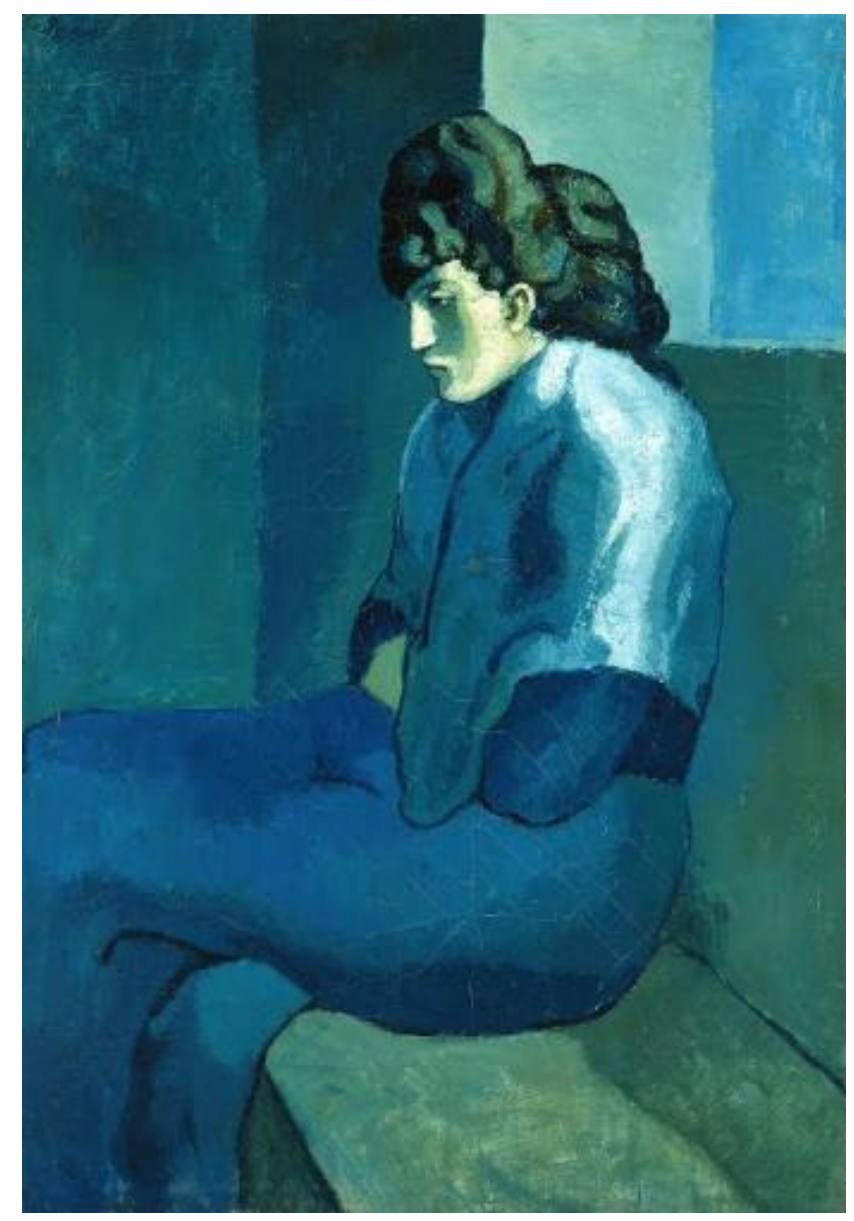

Imagem 13: "Mulher Melancólica” de Pablo Picasso, 1902 (Detroit Institute of Arts Museum)

\section{O Jeans}

A calça jeans é inventada em 1853 por Claude Levi Strauss, um judeu americano que trabalhava vendendo mercadorias, como toldos para carroças e tecidos para barracas. A ideia da peça surgiu quando, em uma de suas viagens, percebeu a necessidade dos mineradores vestirem calças mais resistentes. Devido a maior facilidade de tingimento proporcionada pelo índigo, ocasionou-se de este item do vestuário ser azul (A. PEREIRA, 2011, p. 104 apud PASTOUREAU, SIMONNET, 2008). 


\section{artigos}

O Azul na História da Moda

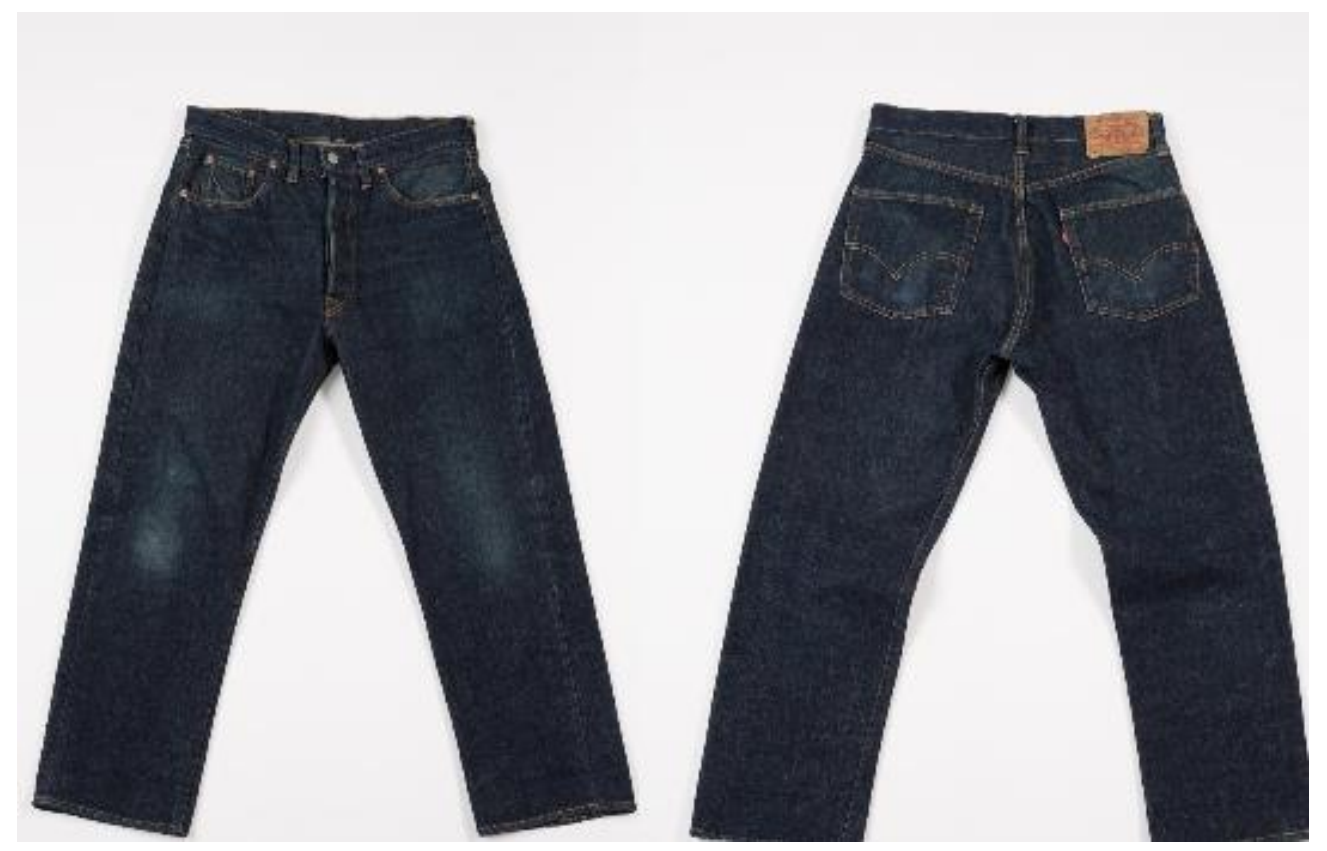

Imagem 14: "'501' jeans Levi Strauss \& Co", 1953, EUA, considerada a "original” (Museum at the Fashion Institute of Technology)

Desde então, a associação ao jeans mudou a forma como as pessoas pensam a cor azul na moda. Em um primeiro momento, com o uso do jeans pela classe trabaIhadora, a coloração ganha uma visão de sobriedade. Nos anos de 1960, o jeans tornou-se símbolo de liberdade, jovialidade e contestação ao ser usado de forma massiva pela juventude da época (A. PEREIRA, 2011, p. 104).

\section{As técnicas japonesas}

No Japão, o azul, muito mais do que uma cor, é o resultado de uma técnica de tingimento tradicional datada de milênios. Segundo um artigo do Journal of Chemical Education (1987, p. 332, tradução nossa), "A técnica tradicional de tingimento chamada ai-zome usa a planta índigo, Tade-Ai (Polygonum tinctrium L.), e tem sido popular no Japão por mais de mil anos". A popularidade desse saber deve-se, principalmente, ao 


\section{artigos}

Ana Júlia Bariani, Anna Gabriela Taguchi, Beatriz Alves, Leandro Silva, Thais Santos

solo fértil de algumas localidades do país, o qual é fruto de inundações que propiciaram o cultivo de um Índigo de alta qualidade (TSAO, HSIEH, CHEN, LIN, 2017, p. 1599).

Atualmente, essa técnica é uma constante de inovação nas roupas de estilistas como Rei Kawakubo e Issey Miayke, que "apresentam uma versão contemporânea do índigo ao combinar métodos tradicionais japoneses com tintas e materiais sintéticos" (MINISTERIO DE CULTURA; KYOTO COSTUME INSTITUTE, 2007, p. 28). Exemplo disso é uma das criações de Rei Kawakubo para a Comme Des Garçons, a qual a designer utiliza a fibra sintética rayon de forma a imitar um tecido de algodão ai-zome. O estampado do tecido neste exemplo simula ser um ai-zome; porém ao invés de empregar a técnica tradicional de gravura, utiliza-se de uma técnica experimental de estampagem" (MINISTERIO DE CULTURA; KYOTO COSTUME INSTITUTE, 2007), p. 140). 


\section{artigos}

O Azul na História da Moda

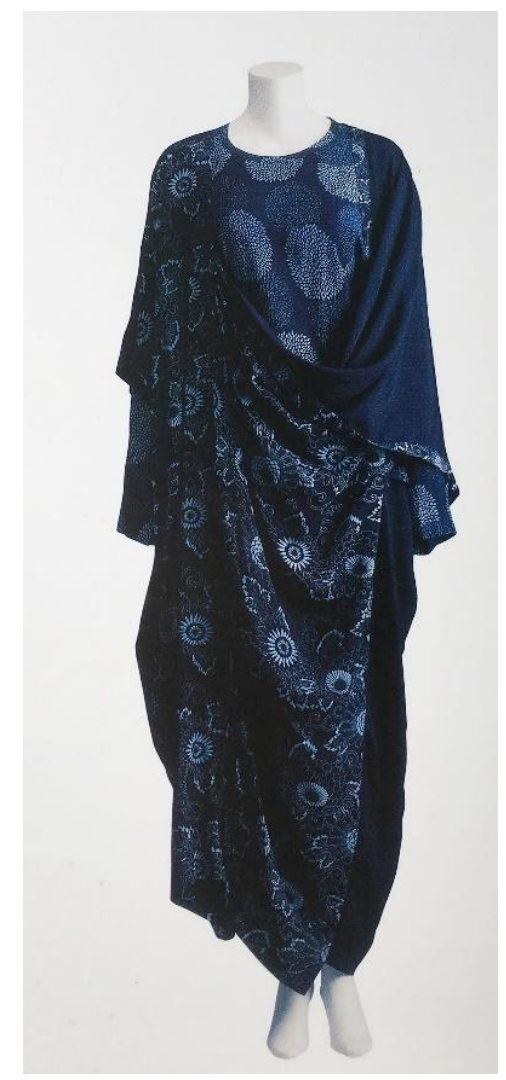

Imagem 15: Vestido e camiseta Rei Kawakubo para Comme Des Garçons imitando ai-zome (Ministerio de Cultura; Kyoto Costume Institute, 2007)

Após ser descoberto em diferentes pigmentos, sintetizado de diversas técnicas e ter sido usado para simbolizar crenças, classes e sentimentos, o azul chega ao século XX, não apenas como uma cor, mas também como um identificador de gênero.

Quando tudo começou: por que meninos usam azul?

A cor azul e rosa são atribuídos aos gêneros masculino e feminino. Isso é mais perceptível durante a infância, época em que artigos para meninos e meninas são predominantemente divididos por cores: o rosa e o azul. 


\section{artigos}

Ana Júlia Bariani, Anna Gabriela Taguchi, Beatriz Alves, Leandro Silva, Thais Santos

Em Pink and Blue: Telling the boys from the girls in America, Jo B. Paoletti (2012, p. 137), argumenta que o código de cor generificado não era comum no Ocidente (em especial nos Estados Unidos), até a década de 1920, nesse momento crianças de até dois ou três anos de idade usavam vestidos brancos idênticos.

Paolo Frassanito e Benedetta Pettorini, em "Pink and Blue: The color of gender" (2008, p. 2), reafirmam o que diz Paoletti (2012, p. 136): associar uma cor a um gênero era uma prática reconhecida no Oeste Europeu e nas Américas, ao vestir crianças a partir de três anos. Segundo eles, a associação que hoje consideramos normal, era o inverso no final do século XIX e início do XX, onde o azul era indicado para meninas, e o rosa para meninos. A dupla ilustra essa afirmação $(2008$, p. 2), com trecho de revistas e catálogos datados do início do século XX, e com um fragmento do romance Little Women (1868): "Amy amarra um laço rosa e um azul nos gêmeos de Meg, Daisy e Demi, para que as pessoas saibam a diferença entre a menina e o menino."

Isso também é observado na seguinte fala de um jornal da época, com a fala: "se você gosta de cor nas roupas das crianças, use rosa para o menino e azul para a menina, se você for um seguidor da convenção/moda" Jornal The Sunday Sentinal, 29 de março de 1914). Além disso, de acordo com o Ladies Home Journal (Junho de 1918)

\footnotetext{
"Houve uma grande diversidade de opiniões sobre o assunto, mas a regra geralmente aceita é rosa para o menino e azul para a menina. A razão é que o rosa sendo uma cor mais decidida e mais forte é mais adequado para o garoto, enquanto o azul, que é mais delicado e meigo, é mais bonito para a garota."
} 


\section{artigos}

\section{O Azul na História da Moda}

Também é possível verificar essa atribuição em outras obras desse período, como Peter Pan lançado em livro em 1902, e adaptado em animação em 1953 pela Walt Disney Pictures.

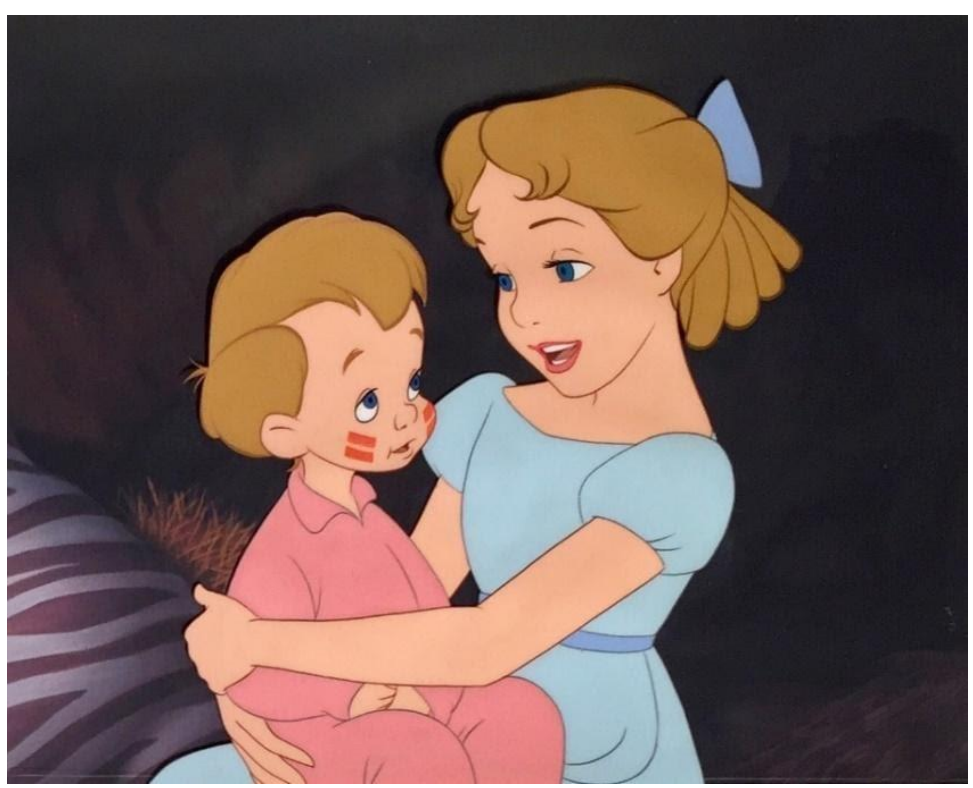

Imagem 16: Wendy e Michael Darling em "Peter Pan," 1953, Walt Disney Studios. (Peter Pan, 1953)

Paoletti $(2012$, p. 137) traz uma tabela publicada pela Time de 1927, apresentando a distribuição das cores nas lojas de departamento e diferentes cidades estadunidenses. Embora muitos próximos, é possível perceber que o rosa é indicado para meninos em 6 das dez cidades. A tabela é apresentada na Imagem 17: 


\section{artigos}

Ana Júlia Bariani, Anna Gabriela Taguchi, Beatriz Alves, Leandro Silva, Thais Santos

\begin{tabular}{|l|l|l|}
\hline City & Boys & Girls \\
\hline Boston- $\begin{array}{r}\text { Mest's's's } \\
\text { Franklin Simon }\end{array}$ & Pink & Blue \\
\cline { 2 - 3 } & Pink & Blue \\
\cline { 2 - 3 } & Blue & Pink \\
\hline $\begin{array}{r}\text { Philadelphia- } \\
\text { John Wanamaker's }\end{array}$ & Blue & Pink \\
\hline $\begin{array}{r}\text { Cleveland- } \\
\text { Marshall Field's }\end{array}$ & Pink & Pink \\
\hline $\begin{array}{r}\text { Chicago- } \\
\text { Maison Blanche }\end{array}$ & Pink & Pink \\
\hline $\begin{array}{c}\text { New Orleans- } \\
\text { San Francisco- } \\
\text { The White House }\end{array}$ & Pink & Blue \\
\hline $\begin{array}{c}\text { Los Angeles- } \\
\text { Bullock's }\end{array}$ & Blue & Blue \\
\hline
\end{tabular}

Source: Time, Nov. 11, 1927

Imagem 17: Tabela de Jo Paoletti. (Pink Is For Boys, [?])

A inversão das atribuições se dá pelas conotações que rosa e azul tinham à época. Pastoureau (2000 apud Pereira 2011, p. 102), afirma que a partir dos séculos XII e XIII, o azul foi relacionado a noções de amor, fé, fidelidade e humildade, e um dos motivos foi sua utilização na produção de imagens cristãs, por ser "a cor da virgem Maria". Por outro lado, o rosa com sua vibração semelhante ao vermelho, era indicada para meninos associada a valores de audácia, coragem e força.

Muitas hipóteses são discutidas sobre como as cores receberam os sentidos generificados que possuem atualmente. O que se observa, é que a partir da Primeira Guerra Mundial, a moda infantil masculina tomou ares militares, e a maior influência para o vestuário foi o estilo marinheiro. 


\title{
artigos
}

\section{O Azul na História da Moda}

Os trajes de marinheiro, usados desde o fim do século XVII com uniforme das escolas da Marinha, foram adaptados ao longo dos séculos para vestir crianças de ambos os gêneros; com meninos de calça e meninas de saia.

\begin{abstract}
"No começo do século XX, esse traje era quase o padrão de roupa cotidiana para meninos e meninas da classe média [...] Na cidade e no campo, em casa e fora de casa, em azul marinho para aquecer ou em branco para o verão e festas" (LURIE 1997, apud TONDING Kern, Monica; SCHEMES, Claudia; CASTILHOS de Araújo, Denise, 2010, p. 406).
\end{abstract}

Em "A moda infantil no século XX: Representações imagéticas na revista do Globo", as autoras Monica Kern Tonding, Claudia Schemes e Denise de Araújo CastiIhos, buscam através da análise da publicação de circulação nacional, descobrir o cenário brasileiro para representação a moda infantil vigente. Então constatam que a moda marinheiro fazia sucesso no país até 1946 na indumentária masculina, enquanto as meninas pararam de utilizar o traje em 1938, adotando uma estética muito similar ao que era usado por mulheres adultas no período.

Outro estilo infantil famoso do começo do século era o Fauntleroy, inspirado no livro "Little Lord Fauntleroy". A vestimenta é descrita como:

"Uma jaqueta preta ou azul safira de veludo e calças usadas com uma camisa branca com um largo colarinho de renda Vandyke. Era completado por uma faixa de seda colorida, meias de seda, sapatilha afivelada, uma boina grande de veludo e cabelos cacheados." (LURIE 1997, apud TONDING Kern, Monica; SCHEMES, Claudia; CASTILHOS de Araújo, Denise, 2010, p.406). 


\section{artigos}

Ana Júlia Bariani, Anna Gabriela Taguchi, Beatriz Alves, Leandro Silva, Thais Santos

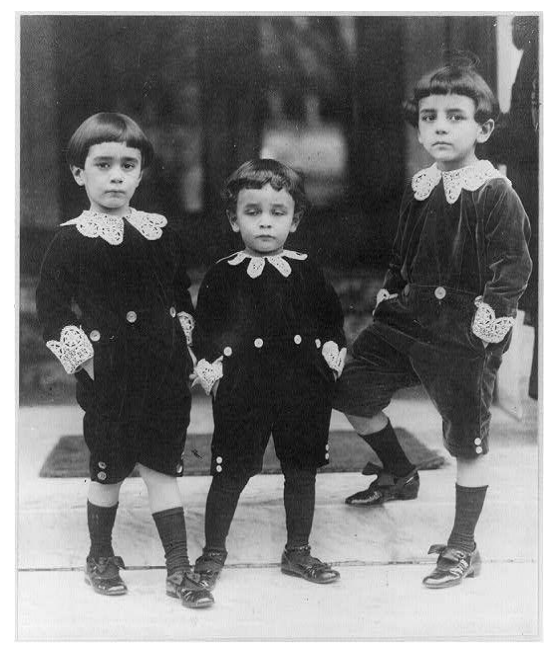

Imagem 18: Meninos em traje de veludo, inspirado por Little Lord Fauntleroy (1909-1932). (Zazzle)

Frassanito e Pettorini (2008, p. 2) levantam outra versão, a de que meninas tenham começado a usar rosa, por uma associação feita na Alemanha nazista entre a cor rosa e a feminilidade. Subvertendo as tradições cristãs europeias em relacionar o azul a Virgem Maria, a Alemanha nazista passa a associar a partir de 1930 o rosa as meninas, e utiliza um triângulo rosa para identificar homossexuais nos campos de concentração.

Depois da Segunda Guerra Mundial, o azul foi extensivamente usado nos uniformes masculinos. Passando a ser associado à masculinidade. A partir de 1940, o rosa foi trabalhado como uma cor de mulher. "Pense rosa" foi o slogan utilizado para convencer as mulheres a abraçar sua feminilidade. (FRASSANITO e PETTORINI, 2008).

A partir de 1950, a imprensa (revistas de moda e comportamento em sua maioria) passaram a recomendar uniformemente que meninos usassem azul e meninas usassem rosa, as atribuições às quais estamos acostumados. 


\section{artigos}

\section{O Azul na História da Moda}

No vestuário masculino, o azul tornou-se uma unanimidade, assumindo grande parte dos significados do preto: como um sub-preto, ou um preto menos formal, o azul-marinho é recomendado para ocasiões sociais importantes e para o trabalho por inspirar respeito, dignidade, e indicar status social e autoridade. (Pastoureau, 2000; Harvey, 2003 apud. Pereira, 2011.)

Em "A invenção da infância generificada: a pedagogia da mídia impressa constituindo as identidades de gênero" Cláudia Amaral dos Santos, analisou criticamente 53 edições do conjunto das publicações brasileiras: Pais \& Filhos, Crescer em Família e Meu Nenê e Família, dos períodos de 2000 a 2002, e suas indicações nos segmentos brinquedos, decoração e moda.

A autora analisa a associação da performance social projetada para meninos e meninas, relacionando a cor rosa e o azul a maneiras de pensar, ser e agir do que se espera do "ser masculino e do ser feminino".

\footnotetext{
"Os indivíduos aprendem desde muito cedo - eu diria que hoje desde o útero a ocupar e/ou a reconhecer seus lugares sociais e aprendem isso em diferentes instâncias do social, através de estratégias sutis, refinadas e naturalizadas que são, por vezes, muito difíceis de reconhecer." (MEYER, apud SANTOS, 2008, p. 4).
}

Isso é exemplificado na Imagem 19, que demonstra um ensaio que reúne meninos e meninas e todos os seus artigos rosas e azuis. (Chamado de The Pink \& Blue Project com o fotógrafo: JeongMee Yong.) 


\section{artigos}

Ana Júlia Bariani, Anna Gabriela Taguchi, Beatriz Alves, Leandro Silva, Thais Santos

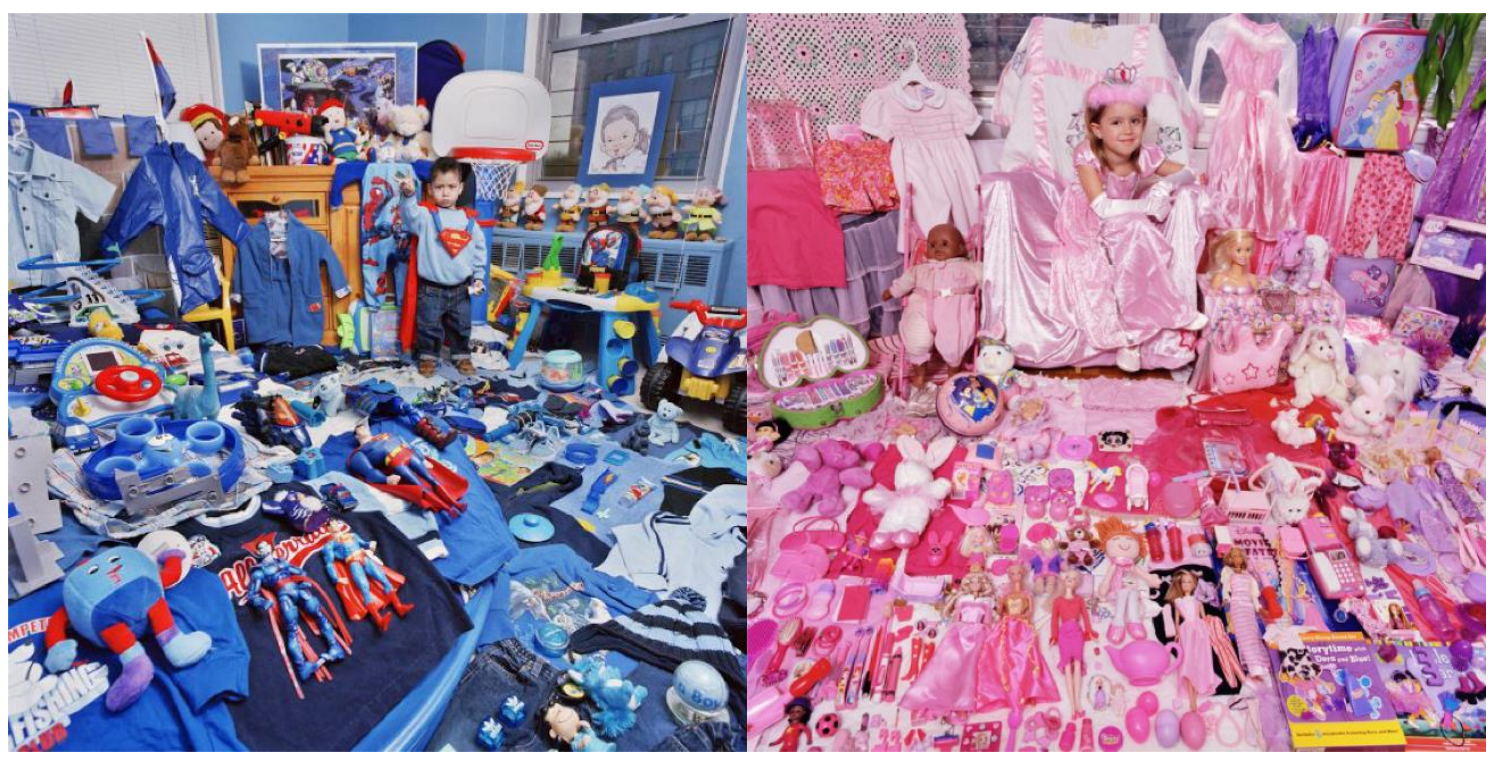

Imagem 19: The Pink \& Blue Project (British Journal of Photography, 2019)

Dutra (apud. Santos, 2008) afirma que "desde a mais tenra infância meninos e meninas vão sendo diferenciados pelo artifício das roupas e sendo ensinados sobre a forma adequada como cada sexo deve se vestir" (p. 10).

Pôde-se observar, que ao longo da história ocidental do azul, os sentidos atribuídos à cor não foram estáticos, mas mudaram em razão da mentalidade e valores de cada época.

Rosa e azul estão associados à concepção do sujeito "mulher e homem", construção essa não restrita apenas ao ambiente familiar, escolar ou social como um todo. No atual contexto brasileiro observa-se uma reafirmação desses valores a partir da declaração da ministra da Mulher, Família e Direitos Humanos, Damares Alves, em 2019. Nela a advogada e pastora evangélica defende uma "nova era" no Brasil, em que meninos vestem azul e meninas vestem rosa (G1, 2019). 


\section{artigos}

\section{O Azul na História da Moda}

\section{Considerações Finais}

Traçar a presença do azul na indumentária ocidental demonstrou-se com uma abordagem dificultada devido à falta de pesquisas relacionadas ao tema, sejam elas nacionais ou internacionais. Em geral, estudos discorrem a respeito da presença da cor em um âmbito geral das artes visuais, sendo em poucos casos citadas aplicações e simbologias do tom no vestuário. Entretanto, seu estudo é de suma importância, pois a trajetória da cor na moda está diretamente relacionada a diferentes contextos sociais, culturais, políticos e comportamentais, permitindo dessa forma uma nova perspectiva da história da humanidade.

Nesse sentido, a falta de dados traz incertezas a respeito de diferentes questões, como, por exemplo, sobre a origem do índigo, um dos principais corantes de tingimento utilizados até a contemporaneidade. Contudo, não é preciso restringir-se somente a esse corante ao se tratar da antiguidade, pois o período é marcado por uma imprecisão sobre a forma de obtenção geral do pigmento, sendo ainda importante ressaltar o caráter indefinido das aplicações da cor no período.

Além disso, a pesquisa do azul exige o emprego de fontes visuais que somente podem ser visualizadas no meio digital, fato que implica em incertezas sobre o tom demonstrado na imagem, pois cada aparelho tecnológico utilizado pode exibir diferentes variantes do pigmento.

Assim, o estudo constrói um conhecimento singular e específico, que, ao trazer um novo foco de pesquisa, contribui de forma positiva para uma nova compreensão da história. 
Ana Júlia Bariani, Anna Gabriela Taguchi, Beatriz Alves, Leandro Silva, Thais Santos

Referências Bibliográficas

ALBUQUERQUE, Márcia Caroline Amaral. Visualidades de Elizabeth I: Reminiscências em Figurinos Contemporâneos. $2^{\circ}$ Congresso Internacional de Memória, Design e Moda. São Paulo. 2015.

ANDRADE, Maria Margarida de. Introdução à Metodologia do trabalho científico. 2 . ed. São Paulo: Atlas, 1997.

ARSENAULT, Natalie. et al. Explorers, Traders, \& Imigrants Tracking the Cultural and Social Impacts of the Global Commodity Trade. Austin: University of Texas, 2008. 69-92 p.

BARTHES, Roland. Sistema de la Moda. Barcelona: Editorial Gustavo Gilli, S.A., 1978. ISBN 84-252-0741-X.

BERNARDES, Bruno José. Síntese do Pigmento Azul da Prússia e sua Utilização para a Produção de Tinta do Tipo Guache: Fundação Educacional do Município de Assis, Assis. 2012.

BON, Olga. A Transformação do Vestir: Um Estudo Sobre Leis Suntuárias, Moda e Modernidade. $\mathbf{1 4}^{\circ}$ Colóquio de Moda - $\mathbf{1 1}^{\circ}$ Edição Internacional, Porto Alegre, Setembro 2018.

BOUCHER, François. História do Vestuário no Ocidente. $2^{\mathrm{a}}$. ed. São Paulo: Cosac \& Naify, 2012.

BOURDIEU, Pierre. A Distinção: critica social do julgamento. 1․ ed. São Paulo: Zouk, 2006. ISBN 978-85-88840-68-3.

BRANDÃO, Angela. Uma história de roupas e de moda para a história da arte. MODOS. Revista de História da Arte. Campinas, v. 1, n.1, p.40-55, jan. 2017. Disponível em: <http://www.publionline. iar.unicamp.br/index.php/mod/article/view/728>

CALANDRINI, Luisa Collyer Lima. AS CORES NA ARTE: Uma experiência cromática. 2018. 47 p. Trabalho de Conclusão de Curso do título de bacharel em Comunicação Visual Design da Escola de Belas Artes da Universidade Federal do Rio de Janeiro (UFRJ). Rio de Janeiro, $2018 . \quad$ Disponível em: https://pantheon.ufrj.br/handle/11422/7049 . Acesso em: 26 de out. 2019. 


\section{artigos}

O Azul na História da Moda

CAMPBELL, Thalita do Valle. Índigo: Resgate do azul vegetal para novas aplicações no design. Pontifícia Universidade Católica do Rio de Janeiro, Rio de Janeiro, 2013. Disponível em:

http://www2.dbd.pucrio.br/pergamum/tesesabertas/1113319_2013_completo.pdf. Acesso em: 20 out. 2019.

CAMPELO, Talita da Silva. A Orientação Educacional e o Estágio na Formação de Professores: Práticas de Tutoria e Supervisão em Questão. Universidade Candido Mendes. Rio de Janeiro, p. 5. 2013.

CARVALHO, Ana Paula Lima.; VICHY, Paola de Lima; VENÂNCIO, Millena Rangel. Jeans na Moda: alternativas sustentáveis. $3^{\circ}$ CONTEXMOD, Rio de Janeiro, 2015.

CARVALHO, Úrsula. História da Indumentária. 2a . ed. Araranguá: Instituto Federal de Educação, Ciência e Tecnologia, 2009.

CARVALHO, Úrsula. Apostila de História da Indumentária. 1ª ed. Florianópolis: Centro Federal de Educação Tecnológica - SC.

CASTRO, Laís Nogueira Corrêa e. ANÁLISE DE ARTEFATOS DO ANTIGO EGITO UTILIZANDO FLUORESCÊNCIA DE RAIOS X. Dissertação de mestrado em Engenharia Nuclear. UFRJ / COPPE, Rio de Janeiro, 2014. Disponível em: http://antigo.nuclear.ufrj.br/MSc\%20Dissertacoes/2014/Dissertacao_Lais_Nogueira.pd f Acesso em: 26 de out. 2019.

CHARTIER, Roger. 0 mundo como representação. Estudos Avançados, São Paulo, v. 5, n. 11, p. 173-191, Janeiro a Abril 1991. ISSN 1806-9592.

CORRÊA, Valdriana Prado. Azul na História da Arte. Universidade Federal do Rio Grande do Sul. Porto Alegre. 2017.

COUTINHO, Iluska. Leitura e análise da Imagem. In: DUARTE, JORGE; BARROS. Métodos e Técnicas de Pesquisa em Comunicação. São Paulo: Editora Atlas, 2009.

CHEN, Mei-En.; HSIEH, Hou-Lan.; LIN, Chun.; TSAO, Er-Yu. Qualitative Research of Indigo Development between Japan and Taiwan. Proceedings of the 2017 IEEE International Conference on Applied System Innovation, Taiwan, 2017.

EVELIN. Renaissance Fashion and Dress Codes. The MET Museum, 2012. Disponível em: $\quad$ <https://www.metmuseum.org/blogs/teen-blog/renaissanceportrait/blog/renaissance-fashion-and-dress-codes>. Acesso em: 25 Outubro 2019. 


\section{artigos}

Ana Júlia Bariani, Anna Gabriela Taguchi, Beatriz Alves, Leandro Silva, Thais Santos

FIADEIRO, José Miguel. O Tingimento de Materiais Têxteis: de Arte a Ciência. Universidade da Beira Interior. Covilhã. 1993.

FRASQUETE, Débora Russi. A Representação da Indumentária como Elemento Midiáti-

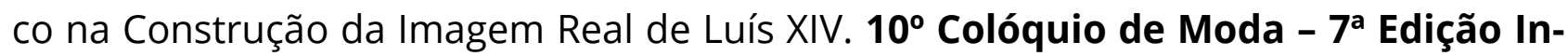
ternacional $1^{\circ}$ Congresso Brasileiro de Iniciação Científica em Design e Moda, Caxias do Sul, 2014.

FRASSANITO, Paolo.; PETTORINI , Benedetta. ( 2008 ). Pink and blue: the color of gender. Child's Nervous System, 24 ( 8 ), 881 - 882.

GLOBOLIVROS. O Livro da História. 1ª. ed. São Paulo: Globo, 2017.

GOOGLE. Day Dress. Google Arts \& Culture. Disponível em: $<$ https://artsandculture.google.com/asset/dress-robe-\%C3\%A0-I-anglaise/JwFM2idm7ZjwA?hl=pt-BR>. Acesso em: 20 Outubro 2019.

GOOGLE. Dress (robe à l'anglaise) c. 1785. Google Arts \& Culture. Disponível em: $<$ https://artsandculture.google.com/asset/dress-robe-\%C3\%A0-I-anglaise/JwFM2idm7ZjwA?hl=pt-BR>. Acesso em: 20 Outubro 2019.

G1. Em vídeo, Damares diz que 'nova era' começou: 'meninos vestem azul e meninas vestem rosa'. G1 Política, 2019. Disponível em:

<https://g1.globo.com/politica/noticia/2019/01/03/em-video-damares-alves-diz-quenova-era-comecou-no-brasil-meninos-vestem-azul-e-meninas-vestem-rosa.ghtml>. Acesso em: 04 Dezembro 2020.

HAGIA SOPHIA MUSEUM. Apse Mosaic. Turquia, [S.d.]. Disponível em: https://ayasofyamuzesi.gov.tr/en/mosa-apse-mosaic. Acesso em: 20 out. 2019.

INÁCIO, Vânia da Conceição Gaudêncio. Cor e Emoção Relação entre Cores do Vestuário e as Emoções atribuídas às Cores, Covilhã, Outubro 2010.

JORDAN, William. Why is blue the world's favorite color? YouGov, 2015. Disponível em: $<$ https://today.yougov.com/topics/international/articles-reports/2015/05/12/why-blueworlds-favorite-color>. Acesso em: 30 Agosto 2019.

JÚNIOR, José Petrúcio de Farias. AS PERIODIZAÇÕES DA HISTÓRIA GERAL E DA HISTÓRIA ANTIGA NOS MANUAIS DE ENSINO DE HISTÓRIA NO BRASIL: limitações e proposições. Outros Tempos, Maranhão, v. 16, n. 28, p. 106-127, 2019. Disponível em: 


\section{artigos}

O Azul na História da Moda

https://www.outrostempos.uema.br/OJS/index.php/outros_tempos_uema/article/view /726/pdf. Acesso em: 20 out. 2019.

KERN, Monica Tonding.; Schemes, Claudia.; Araújo, Denise de Castilho. A MODA INFANTIL NO SÉCULO XX: REPRESENTAÇÕES IMAGÉTICAS NA REVISTA DO GLOBO (1929-1967) Diálogos - Revista do Departamento de História e do Programa de PósGraduação em História, vol. 14, núm. 2,

LIPOVETSKY, Gilles. O império do efêmero A moda e seu destino nas sociedades modernas. São Paulo: Companhia de Bolso, 1987.

LÓPEZ, Sandra Antúnez. El Universo de Luis XIV Através de la Pintura y la Moda. Universidad Complutense de Madrid. Madrid. 2017.

MAJOLO, Mariáh.; VASQUES, Ronaldo Salvador. A INDUMENTÁRIA COMO COMPONENTE DA CLASSIFICAÇÃO SOCIAL: A COR DO VESTUÁRIO COMO ELEMENTO DISTINTIVO NA SOCIEDADE MEDIEVAL E CONTEMPORÂNEA. Jornadas de Estudos Antigos e Medievais, Maringá, Agosto 2013. 2-10.

MARRIOT, Emma. A História do mundo para quem tem pressa. $2^{a}$. ed. Rio de Janeiro: Valentina, 2015.

MINISTERIO DE CULTURA; KYOTO COSTUME INSTITUTE. Moda Chrome: El Color en La Historia de la Moda. Madrid: Ministerio de Cultura, v. Único, 2007.

NEIVA, Eduardo. Imagem, história e semiótica. Anais do Museu Paulista: História e Cultura Material, São Paulo, 1, n. 1, 1993.

PAOLETTI, Jo Barraclough. Clothing and Gender in America: Children's Fashions, 1890-1920. The University of Chicago Press. Source: Signs, Vol. 13, No. 1, Women and the Political Process in the United States (Autumn, 1987), pp. 136-143. eira.pdf. Acesso em: 20 out. 2019.

PAOLETTI, Jo Barraclough. Pink and Blue: Telling the Boys from the Girls in America. Indiana University Press, 2012, 192 p. Acesso em: 24 set. 2019.

PEREIRA, Carla Patrícia. A cor como espelho da sociedade e da cultura: um estudo do sistema cromático do design de embalagens de alimentos. Faculdade de Arquitetura e Urbanismo da Universidade de São Paulo, São Paulo, 2011. Disponível em: https://teses.usp.br/teses/disponiveis/16/16134/tde-19082013-

111907/publico/carlapereira.pdf. Acesso em: 20 out. 2019. 


\section{artigos}

Ana Júlia Bariani, Anna Gabriela Taguchi, Beatriz Alves, Leandro Silva, Thais Santos

PEZZOLO, Dinah. Bueno. Moda e Arte: Releitura no Processo de Criação. 1. ed. São Paulo: Editora Senac, v. 1, 2013.

RIBEIRO, Ana Francisca Cerdeira Rodrigues. Venho das Estrelas: 0 impresentificável no azul. Universidade de Lisboa. Lisboa. 2016.

SANTOS, Cláudia. A Invenção da Infância Generificada: a pedagogia da mídia impressa constituindo as identidades de gênero. 2004. Dissertação (Mestrado em Educação) - Faculdade de Educação, Universidade Federal do Rio Grande do Sul, Porto Alegre, 2004

SERRANO, Maria do Carmo; LOPES, Ana Carreira; SERUYA, Ana Isabel. Plantas Tintureiras. Rev. de Ciências Agrárias [online], v. 31, 2007. ISSN ISSN 0871-018X.

SILVEIRA, Luciana Martha. Introdução à Teoria da Cor. $2^{a}$. ed. CURITIBA: UTFPR, v. Único, 2015.

TORIMOTO, Norboru. An Indigo Plant as a Teaching Material. Journal of Chemical Education, Japão, v. 64, n. 4, Abril 1987.

UNESP. Tipos de Revisão de Literatura. Única. ed. Botucatu: [s.n.], v. Único, 2015.

VICENTE, Tania Aparecida de Souza. Metodologia da análise de imagens. Revista Contracampo, Niterói, n. 12, p. 147-158, Novembro 2008.

VIEIRA, Thaís de Assis. Vestuário na Inglaterra no Século XIV. Universidade Federal do Rio Grande do Sul. Porto Alegre. 2012.

\section{Imagens}

Imagem 1: JORDAN, William. Why is blue the world's favorite color? YouGov, 2015. Disponível em: <https://today.yougov.com/topics/international/articlesreports/2015/05/12/why-blue-worlds-favorite-color>. Acesso em: 30 Agosto 2019.

Imagem 2: METROPOLITAN MUSEUM. Menat necklace from Malqata ca. 1390-1353 B.C. The MET Museum. Disponível em: <https://www.metmuseum.org/art/collection/search/544509>. Acesso em: 17 Setembro 2019. 


\section{artigos}

O Azul na História da Moda

Imagem 3: METROPOLITAN MUSEUM. Shabti of Yuya ca. 1390-1352 B.C. The MET Museum.

Disponível

em: <https://www.metmuseum.org/art/collection/search/548343>. Acesso em: 05 Setembro 2019.

Imagem 4: METROPOLITAN MUSEUM. Blue Kerchief from Tutankhamun's Embalming Cache. The MET Museum. Disponível em: <https://www.metmuseum.org/toah/worksof-art/09.184.217/>. Acesso em: 20 Setembro 2019.

Imagem 5: HAGIA SOPHIA MUSEUM. Apse Mosaic. Turquia, [S.d.]. Disponível em: https://ayasofyamuzesi.gov.tr/en/mosa-apse-mosaic. Acesso em: 20 out. 2019.

Imagem 6: METROPOLITAN MUSEUM. Portrait of a Woman ca. 1480. The MET Museum. Disponível em: <https://www.metmuseum.org/art/collection/search/437322>. Acesso em: 1 Outubro 2019.

Imagem 7: MUSÉE DU LOUVRE. Louis XIV (1638-1715). Musée du Louvre. Disponível em: <https://www.louvre.fr/en/oeuvre-notices/louis-xiv-1638-1715>. Acesso em: 30 Agosto 2019.

Imagem 8: LÓPEZ, Sandra Antúnez. El Universo de Luis XIV Através de la Pintura y la Moda. Univerdidad Complutense de Madrid. Madrid. 2017. Disponivel em: < https://www.academia.edu/39694676/EI_universo_de_Luis_XIV_a_trav\%C3\%A9s_de_la_ pintu-

ra_y_la_moda_Trabajo_de_Fin_de_Grado_de_Historia_del_Arte_Universidad_Complute nse_de_Madrid_ >. Acesso em: 07 Setembro 2019.

Imagem 9: THYSSEN - BORNEMISZA MUSEO NACIONAL. François Boucher La Toilette 1742. Museo Thyssen. Disponível em: <https://www.museothyssen.org/en/collection/artists/boucher-francois/toilette>. Acesso em: 15 Setembro 2019.

Imagem 10: MINISTERIO DE CULTURA; KYOTO COSTUME INSTITUTE. Moda Chrome: El Color en La Historia de la Moda. Madrid: Ministerio de Cultura, v. Único, 2007.

Imagem 11: MINISTERIO DE CULTURA; KYOTO COSTUME INSTITUTE. Moda Chrome: El Color en La Historia de la Moda. Madrid: Ministerio de Cultura, v. Único, 2007.

Imagem 12: METROPOLITAN MUSEUM. First Steps, after Millet 1890. The MET Museum. Disponível em: <metmuseum.org/art/collection/search/436526>. Acesso em: 15 Outubro 2019. 
Ana Júlia Bariani, Anna Gabriela Taguchi, Beatriz Alves, Leandro Silva, Thais Santos

Imagem 13: DETROIT INSTITUTE OF ARTS MUSEUM. Melancholy Woman. Detroit Ins-

titute of Arts Museum. Disponível em:
<https://www.dia.org/art/collection/object/melancholy-woman-57081>. Acesso em: 30 Setembro 2019.

Imagem 14: FASHION INSTITUTE OF TECHNOLOGY. Denim: Fashion's Frontier. The Museum at FIT. Disponível em: <http://www.fitnyc.edu/museum/exhibitions/denim.php>. Acesso em: 17 Outubro 2019.

Imagem 15: MINISTERIO DE CULTURA; KYOTO COSTUME INSTITUTE. Moda Chrome: El Color en La Historia de la Moda. Madrid: Ministerio de Cultura, v. Único, 2007.

Imagem 16: PETER PAN. Direção: Clyde Geronimi; Wilfred Jackson e Hamilton Luske. Produção: Walt Disney. [S.I.]: Walt Disney Animation Studios. 1953. Acesso em: 05 de Outubro de 2019.

Imagem 17: PAOLETTI, Jo B. Pink is For Boys. Gender Mystique. Disponível em: <https://www.pinkisforboys.org/gallery.html>. Acesso em: 03 Setembro 2019.

Imagem 18: ZAZZLE. Kids in Little Lord Fauntleroy Suits 1914 Poster. Zazzle. Disponível em: <https://www.zazzle.com/kids_in_little_lord_fauntleroy_suits_1914_poster228165889324019641>. Acesso em: 10 Outubro 2019.

Imagem 19: SMYTH, Diane. The Pink and Blue Projects by JeongMee Yoon. British Journal of Photography, 2019. Disponivel em: <https://www.bjponline.com/2019/01/jeongmee-yoon-pink-blue/>. Acesso em: 26 Setembro 2019. 